\title{
The environmental and evolutionary history of Lake Ohrid (FYROM/Albania): interim results from the SCOPSCO deep drilling project
}

Bernd Wagner $^{1}$, Thomas Wilke ${ }^{2}$, Alexander Francke ${ }^{1}$, Christian Albrecht ${ }^{2}$, Henrike Baumgarten ${ }^{3}$, Adele Bertini $^{4}$, Nathalie Combourieu-Nebout ${ }^{5}$, Aleksandra Cvetkoska ${ }^{6}$, Michele D’Addabbo $^{7}$, Timme H. Donders ${ }^{6}$, Kirstin Föller ${ }^{2}$, Biagio Giaccio $^{8}$, Andon Grazhdani ${ }^{9}$, Torsten Hauffe ${ }^{2}$, Jens Holtvoeth ${ }^{10}$, Sebastien Joannin ${ }^{11}$, Elena Jovanovska ${ }^{2}$, Janna Just $^{1}$, Katerina Kouli ${ }^{12}$, Andreas Koutsodendris ${ }^{13}$, Sebastian Krastel ${ }^{14}$, Jack H. Lacey ${ }^{15,16}$, Niklas Leicher ${ }^{1}$, Melanie J. Leng ${ }^{15,16}$, Zlatko Levkov ${ }^{17}$, Katja Lindhorst ${ }^{14}$, Alessia Masi ${ }^{18}$, Anna M. Mercuri ${ }^{19}$, Sebastien Nomade ${ }^{20}$, Norbert Nowaczyk $^{21}$, Konstantinos Panagiotopoulos ${ }^{1}$, Odile Peyron ${ }^{11}$, Jane M. Reed ${ }^{22}$, Eleonora Regattieri ${ }^{1,8}$, Laura Sadori $^{18}$, Leonardo Sagnotti ${ }^{23}$, Björn Stelbrink ${ }^{2}$, Roberto Sulpizio ${ }^{7,24}$, Slavica Tofilovska ${ }^{17}$, Paola Torri ${ }^{19}$, Hendrik Vogel $^{25}$, Thomas Wagner ${ }^{26}$, Friederike Wagner-Cremer ${ }^{6}$, George A. Wolff ${ }^{27}$, Thomas Wonik ${ }^{3}$, Giovanni Zanchetta ${ }^{28}$, and Xiaosen S. Zhang ${ }^{29}$

${ }^{1}$ Institute of Geology and Mineralogy, University of Cologne, Cologne, Germany

${ }^{2}$ Department of Animal Ecology \& Systematics, Justus Liebig University Giessen, Giessen, Germany

${ }^{3}$ Leibniz Institute for Applied Geophysics (LIAG), Hanover, Germany

${ }^{4}$ Dipartimento di Scienze della Terra, Università di Firenze, Firenze, Italy

${ }^{5}$ CNRS UMR 7194, Muséum National d'Histoire Naturelle, Institut de Paléontologie Humaine, Paris, France

${ }^{6}$ Palaeoecology, Department of Physical Geography, Utrecht University, Utrecht, the Netherlands

${ }^{7}$ Dipartimento di Scienze della Terra e Geoambientali, University of Bari, Bari, Italy

${ }^{8}$ Istituto di Geologia Ambientale e Geoingegneria - CNR, Rome, Italy

${ }^{9}$ Faculty of Geology and Mineralogy, University of Tirana, Tirana, Albania

${ }^{10}$ School of Chemistry, University of Bristol, Bristol, UK

${ }^{11}$ CNRS UMR 5554, Institut des Sciences de l'Evolution de Montpellier, Université de Montpellier, Montpellier, France

${ }^{12}$ Faculty of Geology and Geoenvironment, National and Kapodistrian University of Athens, Athens, Greece

${ }^{13}$ Paleoenvironmental Dynamics Group, Institute of Earth Sciences, Heidelberg University, Heidelberg, Germany

${ }^{14}$ Institute of Geosciences, Christian-Albrechts-Universität zu Kiel, Kiel, Germany

${ }^{15}$ Centre for Environmental Geochemistry, School of Geography, University of Nottingham, Nottingham, UK

${ }^{16}$ NERC Isotope Geosciences Facilities, British Geological Survey, Keyworth, Nottingham, UK

${ }^{17}$ Institute of Biology, Saints Cyril and Methodius University of Skopje, Skopje, Former Yugoslav Republic of Macedonia

${ }^{18}$ Dipartimento di Biologia Ambientale, Università di Roma "La Sapienza", Rome, Italy

${ }^{19}$ Dipartimento di Scienze della Vita, Laboratorio di Palinologia e Paleobotanica, Università di Modena e Reggio Emilia, Modena, Italy

${ }^{20}$ Laboratoire des Sciences du Climat et de 1'Environnement, UMR 8212, CEA/CNRS/UVSQ et Université Paris-Saclay 91198 Gif-Sur-Yvette, France

${ }^{21}$ Helmholtz Centre Potsdam, GFZ German Research Centre for Geosciences, Potsdam, Germany

${ }^{22}$ Geography, School of Environmental Sciences, University of Hull, Hull, UK

${ }^{23}$ Istituto Nazionale di Geofisica e Vulcanologia, Rome, Italy

${ }^{24}$ IDPA-CNR, via M. Bianco 9, Milan, Italy

${ }^{25}$ Institute of Geological Sciences and Oeschger Centre for Climate Change Research, University of Bern, Bern, Switzerland

${ }^{26}$ The Lyell Centre, Heriot-Watt University, Edinburgh, UK

${ }^{27}$ Department of Earth, Ocean and Ecological Sciences, School of Environmental Sciences, University of Liverpool, Liverpool, UK

${ }^{28}$ Dipartimento di Scienze della Terra, University of Pisa, Pisa, Italy 
${ }^{29}$ Institute of Loess Plateau, Shanxi University, Taiyuan, China

Correspondence to: Bernd Wagner (wagnerb@uni-koeln.de)

Received: 2 November 2016 - Discussion started: 1 December 2016

Revised: 15 March 2017 - Accepted: 20 March 2017 - Published: 20 April 2017

Abstract. This study reviews and synthesises existing information generated within the SCOPSCO (Scientific Collaboration on Past Speciation Conditions in Lake Ohrid) deep drilling project. The four main aims of the project are to infer (i) the age and origin of Lake Ohrid (Former Yugoslav Republic of Macedonia/Republic of Albania), (ii) its regional seismotectonic history, (iii) volcanic activity and climate change in the central northern Mediterranean region, and (iv) the influence of major geological events on the evolution of its endemic species. The Ohrid basin formed by transtension during the Miocene, opened during the Pliocene and Pleistocene, and the lake established de novo in the still relatively narrow valley between 1.9 and $1.3 \mathrm{Ma}$. The lake history is recorded in a $584 \mathrm{~m}$ long sediment sequence, which was recovered within the framework of the International Continental Scientific Drilling Program (ICDP) from the central part (DEEP site) of the lake in spring 2013. To date, 54 tephra and cryptotephra horizons have been found in the upper $460 \mathrm{~m}$ of this sequence. Tephrochronology and tuning biogeochemical proxy data to orbital parameters revealed that the upper $247.8 \mathrm{~m}$ represent the last $637 \mathrm{kyr}$. The multi-proxy data set covering these $637 \mathrm{kyr}$ indicates longterm variability. Some proxies show a change from generally cooler and wetter to drier and warmer glacial and interglacial periods around $300 \mathrm{ka}$. Short-term environmental change caused, for example, by tephra deposition or the climatic impact of millennial-scale Dansgaard-Oeschger and Heinrich events are superimposed on the long-term trends. Evolutionary studies on the extant fauna indicate that Lake Ohrid was not a refugial area for regional freshwater animals. This differs from the surrounding catchment, where the mountainous setting with relatively high water availability provided a refuge for temperate and montane trees during the relatively cold and dry glacial periods. Although Lake Ohrid experienced significant environmental change over the last $637 \mathrm{kyr}$, preliminary molecular data from extant microgastropod species do not indicate significant changes in diversification rate during this period. The reasons for this constant rate remain largely unknown, but a possible lack of environmentally induced extinction events in Lake Ohrid and/or the high resilience of the ecosystems may have played a role.

\section{Introduction}

Systematic limnological studies started in the early 20th century and were first carried out in Europe, for example at Lake Geneva (e.g. Forel, 1901), a number of lakes in Germany (e.g. Thienemann, 1918), and at Lake Ohrid on the Balkan Peninsula (reviewed in Stanković, 1960). These initial studies focused on hydrological data, such as temperature, dissolved oxygen, and bottom morphology, and on biological data, such as the distribution and ecology of lake biota. Analytical and technological advances in the following decades facilitated a more comprehensive understanding of the interactions between catchment dynamics, hydrology, and the living world of lakes. This led to the establishment of new institutions, such as the Hydrobiological Institute at Lake Ohrid in 1935 (Stanković, 1960).

Besides analyses in extant lakes, early scientists were also interested in studying past changes in lake systems, and palaeolimnology, a sub-discipline of limnology, was established in the 1920s. This field started with the collection of sediment cores from lakes to interpret stratigraphic data on plant and animal fossils as a record of the lake's history (National Research Council, 1996). Particularly with the establishment of radiometric dating methods in the 1950s and 1960s, palaeolimnological studies developed into a powerful tool for long- and short-term reconstructions of the climatic and environmental history of lakes and their catchments.

One of the most important developments in palaeolimnological work has been the formation of a multi-national continental drilling program - the International Continental Scientific Drilling Program (ICDP). The Potsdam Conference, conducted in 1993, defined the scientific and management needs for the ICDP and declared Lake Ohrid, Europe's oldest freshwater lake, as an ICDP target site.

One of the most outstanding characteristics of Lake Ohrid, besides its presumed old age, is its high degree of endemic biodiversity. With more than 300 described eukaryotic endemic taxa (Föller et al., 2015), Lake Ohrid belongs to the most biodiverse ancient lakes, i.e. lakes that have continuously existed for $>100 \mathrm{kyr}$ (Albrecht and Wilke, 2008). If its surface area is taken into account, it may have the highest endemic biodiversity amongst all lakes worldwide. Though Lake Ohrid has long been considered to be of Tertiary age, estimates vary considerably, between ca. 2 and $10 \mathrm{Ma}$ (reviewed in Albrecht and Wilke, 2008). Likewise, its limnological origin remains poorly understood, and hypotheses in- 
clude palaeogeographical connections to former marine or brackish water systems and a de novo formation from springs and/or rivers (see also Albrecht and Wilke, 2008, for further information and references therein).

The unique characteristics of Lake Ohrid, together with the lack of knowledge regarding its origin, precise age, and limnological/biological evolution, provided the main motivation to establish an international scientific deep drilling project. Its continuous existence over a long timescale together with an extraordinary degree of endemic biodiversity made Lake Ohrid an ideal "natural laboratory" to study the links between geological and biological evolution and to unravel the driving forces of speciation, leading to the interdisciplinary project Scientific Collaboration on Past Speciation Conditions in Lake Ohrid (SCOPSCO). The four major aims of the SCOPSCO project are to (i) obtain more information on the age and origin of Lake Ohrid, (ii) unravel the regional seismotectonic history including effects of major earthquakes and associated mass-wasting events, (iii) obtain a continuous record containing information on Quaternary volcanic activity and climate change in the central northern Mediterranean region, and (iv) evaluate the influence of major geological events on biotic evolution and the generation of the observed extraordinary degree of endemic biodiversity (Wagner et al., 2014). Based on several site surveys and studies conducted between 2004 and 2011, an ICDP drilling campaign at Lake Ohrid was carried out in spring 2013 using the Deep Lake Drilling System (DLDS) from the Drilling, Observation and Sampling of the Earth's Continental Crust (DOSECC) consortium. In total, more than $2100 \mathrm{~m}$ of sediments were recovered from four drill sites, with a maximum penetration of $569 \mathrm{~m}$ below lake floor (b.l.f.) at the main drill site (DEEP) in the central part of Lake Ohrid (Fig. 1).

Subsampling and analyses are ongoing, but initial, detailed results of geological and biological investigations of the upper $247.8 \mathrm{~m}(637 \mathrm{ka})$ of the DEEP sediment sequence and newer results from biological studies on the extant fauna of Lake Ohrid were recently published in a special issue in the journal Biogeosciences (Wagner et al., 2015). The aim of this paper is to review and synthesise the results of the 14 individual papers of this special issue and to complement them with information from former and new studies in order to provide a comprehensive overview on progress towards achieving the four main aims defined for SCOPSCO.

\section{Site information}

Lake Ohrid is a transboundary lake shared between the Former Yugoslav Republic of Macedonia (FYROM) and the Republic of Albania (Fig. 1). The lake is located at $693.5 \mathrm{~m}$ above sea level (a.s.l.) and has a maximum length of $30.4 \mathrm{~km}$ $(\mathrm{N}-\mathrm{S})$, a maximum width of $14.7 \mathrm{~km}$ (W-E), a surface area of $358 \mathrm{~km}^{2}$, and a tub-shaped bathymetry with a maximum water depth of $293 \mathrm{~m}$, a mean water depth of $\sim 151 \mathrm{~m}$, and a to- tal volume of $50.7 \mathrm{~km}^{3}$ (Fig. 1; Popovska and Bonacci, 2007; Lindhorst et al., 2012). Water loss occurs by evaporation $\left(13.0 \mathrm{~m}^{3} \mathrm{~s}^{-1}\right)$ and by the artificially controlled surface outflow in the northern part of the lake, river Crni Drim, which flows into the Adriatic Sea. Outflow rates vary between $22.0 \mathrm{~m}^{3} \mathrm{~s}^{-1}$ (Popovska and Bonacci, 2007) and $24.9 \mathrm{~m}^{3} \mathrm{~s}^{-1}$ (Matzinger et al., 2006, and references therein), depending on seasonal and long-term variations in water level of up to $\sim 1.5 \mathrm{~m}$ between 1950 and 2000 (Popovska and Bonacci, 2007). The total water loss can be averaged to $\sim 36.5 \mathrm{~m}^{3} \mathrm{~s}^{-1}$ and is balanced by water input from surface and sublacustrine springs, direct precipitation, and rivers. Published data of the annual precipitation in the watershed of Lake Ohrid vary between 698.3 and $1194.0 \mathrm{~mm} \mathrm{yr}^{-1}$, with higher precipitation at higher altitudes and an average of $907 \mathrm{~mm} \mathrm{yr}^{-1}$ (Popovska and Bonacci, 2007). The average monthly rainfall is highest in winter, with a maximum in November and December, and lowest between June and September. The lake level, however, is highest in June due to snowmelt input and lowest in October and November, before the start of autumn rainfall (Popovska and Bonacci, 2007). The seasonal and long-term variations in water budget allow only an approximation of the water input from the various sources. Direct precipitation and river inflows $(45 \%)$ as well as surface and sublacustrine karst springs ( $55 \%$ ) contribute to the overall water input (Matzinger et al., 2006). The river Sateska, which was previously a direct tributary of the Crni Drim, was artificially diverted into Lake Ohrid in 1962 and is today the largest surface river inflow with a contribution of $\sim 15 \%$ of the total inflow of Lake Ohrid (Matzinger et al., 2006; Popovska and Bonnacci, 2007). The karst springs are located primarily along the eastern shoreline of the lake (Fig. 1) and karst waters originate in almost equal proportions from mountain range precipitation and via outflow from Lake Prespa, located $\sim 10 \mathrm{~km}$ to the east and $\sim 155 \mathrm{~m}$ higher in altitude (Matzinger et al., 2006). Calculating the ratio between the volume of Lake Ohrid $\left(50.7 \mathrm{~km}^{3}\right)$ and its outflow $\left(\sim 23.5 \mathrm{~m}^{3} \mathrm{~s}^{-1}\right)$ results in a theoretical water residence time of $\sim 70$ years (Matzinger et al., 2006; Popovska and Bonacci, 2007). This theoretical residence time is reduced to $\sim 45$ years, when evaporation is taken into account and calculated with the total water output or input $\left(\sim 36.5 \mathrm{~m}^{3} \mathrm{~s}^{-1}\right)$. However, the real water residence time is probably much higher, as sporadic mixing intervals or incomplete mixing, variations in wind stress, or kinetic effects of inflow water entering may affect the lake's hydrology (Ambrosetti et al., 2003). For example, Lago Maggiore in Italy was classified as a holo-oligomictic lake prior to 1970, when the upper 150$200 \mathrm{~m}$ of the water column mixed every winter and complete mixing occurred irregularly every few years (Ambrosetti et al., 2003). This is similar to Lake Ohrid today (Matzinger et al., 2006) and the real residence time at Lago Maggiore is higher by a factor of 3 to 4 than the theoretical residence time (Ambrosetti et al., 2003). 

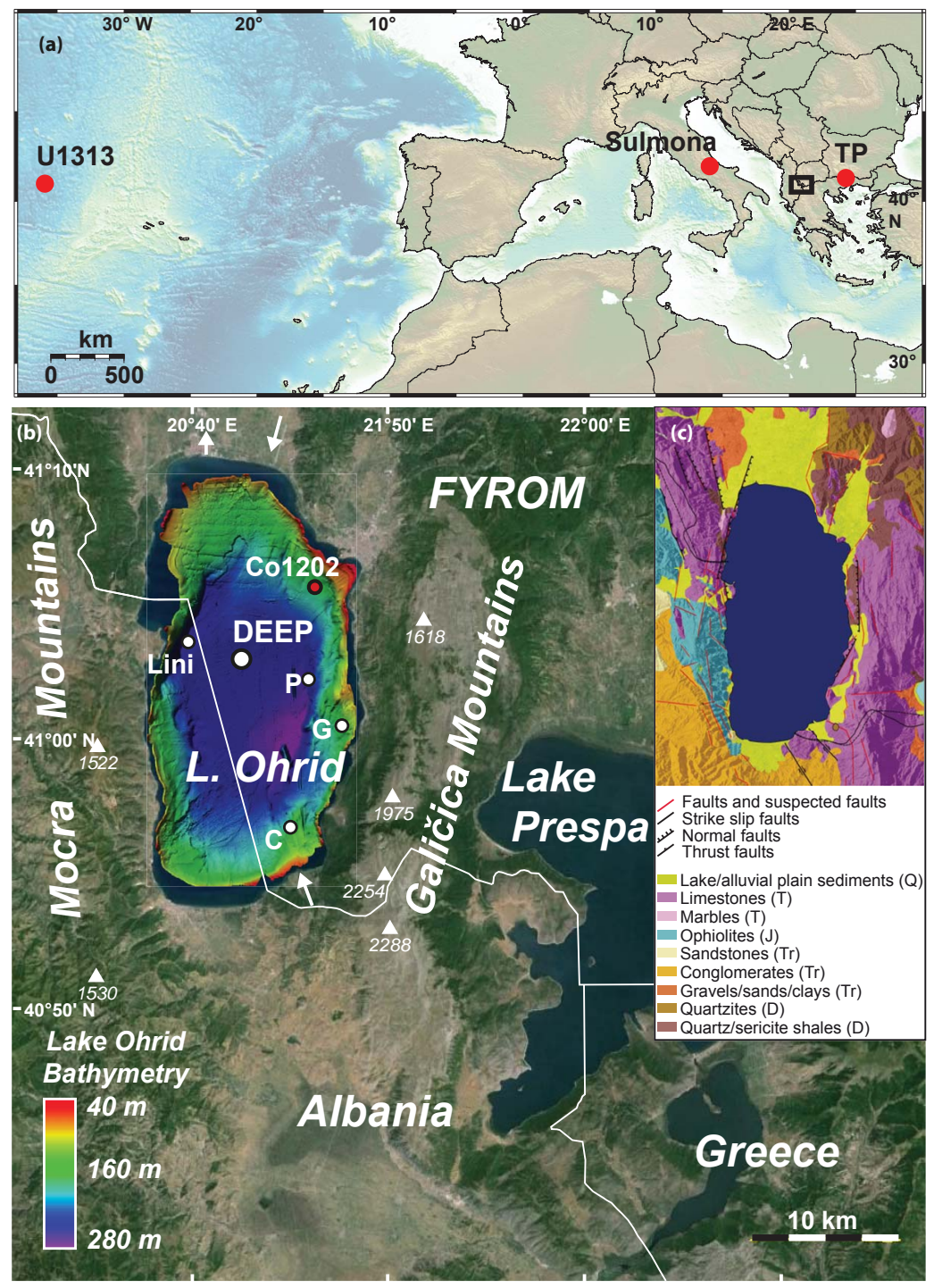

Figure 1. (a) Location of Lake Ohrid (black rectangle) on the Balkan Peninsula at the border of the Former Yugoslav Republic of Macedonia (FYROM) and the Republic of Albania. Other records mentioned in the text are indicated by red dots (core U1313 in the North Atlantic, Sulmona basin in Italy, Tenaghi Philippon (TP) in Greece). (b) Map of the area of lakes Ohrid and Prespa and bathymetric map of Lake Ohrid (from Lindhorst et al., 2015). Coring locations of piston core Co1202 (red; Vogel et al., 2010a) and ICDP sites (white) are shown, with DEEP and Lini sites mentioned in the text. Secondary ICDP sites P (Pestani), G (Gradiste), and C (Cerava) are not mentioned in the text. (c) Geological map of the Lake Ohrid catchment (modified from Lindhorst et al., 2015).

Physical and chemical characteristics of Lake Ohrid have been provided in several publications and annual reports (e.g. Watzin et al., 2002; Matzinger et al., 2006; Jordanoski et al., 2004, 2005; Naumoski et al., 2007; Schneider et al., 2014). Average total phosphorous (TP) concentrations of $<10 \mathrm{mg} \mathrm{m}^{-3}$ and Secchi depths ranging between 7 and $16 \mathrm{~m}$ characterise the pelagic zone of Lake Ohrid as oligotrophic. These oligotrophic conditions explain why bottom water oxygen concentrations of above $4 \mathrm{mg} \mathrm{L}^{-1}$ are recorded even during years without complete overturn (Matzinger et al., 2006). The surface water temperature varies between $\sim 25^{\circ} \mathrm{C}$ in summer and $\sim 7^{\circ} \mathrm{C}$ in winter, while bottom water temperatures are $\sim 6^{\circ} \mathrm{C}$ throughout the year. The boundary between epilimnion and hypolimnion is between 30 and $50 \mathrm{~m}$, depending on the season. The $\mathrm{pH}$ decreases from 8.68.9 in surface waters to $7.9-8.4$ in bottom waters. The specific conductivity is around $200 \mu \mathrm{S} \mathrm{cm}^{-1}$ in surface waters and around $150 \mu \mathrm{S} \mathrm{cm}^{-1}$ at $50-200 \mathrm{~m}$ water depth and increases again in deeper waters. The concentration of $\mathrm{Si}$ is lowest in the trophogenic surface waters, where it is taken up by diatoms, and increases gradually to $<2 \mathrm{mg} \mathrm{L}^{-1}$ in bottom waters (Stanković, 1960). The littoral part of the lake ex- 
hibits a slightly higher trophic state (Schneider et al., 2014). These meso- to slightly eutrophic conditions in relatively shallow waters might be due to a direct input of nutrients from the catchment, higher temperatures, and increasing anthropogenic pollution over the last several decades (Kostoski et al., 2010; Schneider et al., 2014). The macrophytic flora in the littoral part of Lake Ohrid can be subdivided into different belts, with Chara species in water depths between 3 and $30 \mathrm{~m}$, Potamogeton species in shallow waters, and a discontinuous belt of Phragmites australis along the shore (Albrecht and Wilke, 2008; Imeri et al., 2010).

The vegetation in the catchment of Lake Ohrid can be categorised along altitudinal belts (see Filipovski et al., 1996; Matevski et al., 2011). Grasslands and agricultural land are encountered in the littoral zone and the lowlands surrounding the lake, followed by forests dominated by different species of both deciduous and semi-deciduous oaks (Quercus cerris, $Q$. frainetto, $Q$. petraea, $Q$. pubescens, and $Q$. trojana) and hornbeams (Carpinus orientalis, Ostrya carpinifolia) up to $1600 \mathrm{~m}$ a.s.l. Mesophilous/montane species such as Fagus sylvatica, Carpinus betulus, Corylus colurna, Acer obtusatum, and Abies borisii-regis dominate at higher altitudes up to $1800 \mathrm{~m}$ a.s.l. Due to intense grazing, the timberline is between 1600 and $1900 \mathrm{~m}$ a.s.l. Reforestation is now slowly replacing the existing alpine pasture lands and grasslands at and above this altitude (Matevski et al., 2011). Sparse populations of several Pinus species, considered to be Tertiary relics, are located in the wider region of Lake Ohrid (Sadori et al., 2016). Em et al. (1985) considered the Ohrid-Prespa region to be a refugial area with remains of vegetation of other species (e.g. Pinus heldreichii, Quercus trojana, Juniperus excelsa, Aesculus hippocastanum, Genista radiata).

The highest mountains in the Lake Ohrid watershed, which encompasses $1002 \mathrm{~km}^{2}$ sensu stricto and $2393 \mathrm{~km}^{2}$ including the Lake Prespa catchment, reach $1532 \mathrm{~m}$ a.s.l. in the Mocra Mountains to the west, and $2288 \mathrm{~m}$ a.s.l. in the Galičica Mountains to the east of the lake. The average altitude of the Lake Ohrid watershed is 1109 m a.s.l. About $12 \%$ of its watershed is located at an altitude above $1500 \mathrm{~m}$ a.s.l. (Popovska and Bonacci, 2007). Intensely karstified Triassic limestones and Devonian siliciclastic bedrock dominate in the south-eastern, eastern, and north-western catchment (e.g. Wagner et al., 2009; Lindhorst et al., 2015). Ultramafic metamorphic and magmatic rocks including ophiolites of Jurassic and Cretaceous age crop out in the west. The plains at the northern, north-eastern, and southern lake shore are covered by Quaternary sediments.

\section{Material and methods}

\subsection{Field work}

\subsubsection{Seismic and hydro-acoustic surveys}

Seismic and hydro-acoustic surveys were carried out on Lake Ohrid between 2004 and 2009. Parametric sediment echosounder profiles span $>900 \mathrm{~km}$ in length and were collected at operating frequencies between 6 and $12 \mathrm{kHz}$ (SES96 light in 2004 and SES 2000 compact in 2007 and 2008, Innomar Co.). These frequencies allowed up to $60 \mathrm{~m}$ of penetration into the sediments at a vertical resolution of $\sim 20 \mathrm{~cm}$. Over $500 \mathrm{~km}$ of profiles were collected by multichannel seismic surveys using a Mini GI Air Gun $(0.2 \mathrm{~L}$ in 2007 and $0.1 \mathrm{~L}$ in 2008) and a 16-channel $100 \mathrm{~m}$ long streamer. The Mini GI Air Gun operated at frequencies between 150 and $500 \mathrm{~Hz}$ and allowed a maximum penetration of several hundred metres at a vertical resolution of $\sim 2 \mathrm{~m}$. A multibeam survey in 2009, using an ELAC Seabeam 1180 sonar system, was used to acquire detailed bathymetric information of the lake floor below $\sim 20 \mathrm{~m}$ water depth. More detailed information on the technical specifications of the seismic and hydro-acoustic systems, their settings, the location of the individual profiles, and the operational logistics can be found in Wagner et al. (2014) and Lindhorst et al. (2015).

\subsubsection{Coring and on-site analyses}

Several gravity and piston coring campaigns were carried out from local research vessels or small floating platforms (UWITEC Co.) on Lake Ohrid between 2004 and 2011. Whereas surface sediments collected by gravity corer throughout the basin were used to reconstruct the recent settings and the most recent history of Lake Ohrid (e.g. Matzinger et al., 2007; Wagner et al., 2008a; Vogel et al., 2010c), piston cores with a maximum penetration of $\sim 15 \mathrm{~m}$ b.l.f. were collected from the lateral parts of the lake, where the water depth did not exceed $150 \mathrm{~m}$ (e.g. Wagner et al., 2008b, 2009; Belmecheri et al., 2009; Vogel et al., $2010 \mathrm{a}, \mathrm{b})$. These piston cores enabled a reconstruction of the environmental, climatic, and tephrostratigraphic history of the lake back to $\sim 140 \mathrm{ka}$ and provided fossil records of pollen (Wagner et al., 2009), molluscan faunas (Albrecht et al., 2010), and diatom floras (Reed et al., 2010).

Based on the site surveys, five primary target sites in Lake Ohrid were proposed for the SCOPSCO ICDP project. One of these sites, Lini (Co1262; Fig. 1), was cored in 2011 using a UWITEC platform and piston corer at $260 \mathrm{~m}$ water depth. Although the Co1262 sediment sequence reached only $10.08 \mathrm{~m}$ b.l.f., this is the most complete Holocene sequence retrieved to date. Studies on the core material contributed to a better understanding of the tectonic activity (Wagner et al., 2012) and the Late Glacial to Holocene environmental history of the region (Lacey et al., 2015; Zhang et al., 2016). 
The remaining four sites were cored in spring 2013 using the DLDS (Wagner et al., 2014; Francke et al., 2016). At the main site, the DEEP site in the central part of the Lake Ohrid basin, six holes (5045-1A to 5045-1F) were drilled with a maximum depth of $\sim 569 \mathrm{~m}$ b.l.f. (Fig. 1) and an average distance of $\sim 40 \mathrm{~m}$ between the individual holes (for details see Francke et al., 2016). In total, $\sim 1500 \mathrm{~m}$ of sediment cores were recovered, cut into up to $1 \mathrm{~m}$ long segments, and stored in a reefer at $4{ }^{\circ} \mathrm{C}$ before being shipped to the University of Cologne, Germany, for further processing.

On-site analyses during the 2013 deep drilling campaign included borehole logging, core scanning for magnetic susceptibility (MS), and sedimentological and palaeobiological core catcher analyses. Borehole logging was carried out with various probes at all four drill sites. The logging tools comprised MS, dipmeter, resistivity, borehole televiewer, spectral gamma ray (SGR), and sonic. While SGR was run through the drill pipe in order to prevent caving of sediments into the drill hole, all other tools were run in 40-50 m long openhole sections except for the uppermost $30 \mathrm{~m}$ b.l.f., which was kept open with drill pipes to allow re-entry of other probes. Details of the borehole logging tools, logging speed, and vertical resolution are given in Baumgarten et al. (2015). Check shots were recorded for hole 5045-1C, allowing a very good seismic-to-core correlation for the DEEP site.

In order to determine volume-specific MS on the sediment cores and to carry out preliminary core correlation, all cores were scanned on site at a resolution of $2 \mathrm{~cm}$ with a Bartington MS2C loop sensor (10 cm internal diameter) mounted on a multi-sensor core logger (MSCL, Geotek, UK). Smear slide analyses of core catcher material ( $\sim 3 \mathrm{~m}$ resolution) from holes 5045-1B and 5045-1C were used for on-site diatom analyses (Wagner et al., 2014).

\subsubsection{Laboratory work}

The geological work carried out on the gravity and piston cores from the site surveys and on the cores obtained during the ICDP drilling campaign comprises a broad suite of analytical methods. It includes lithological description after core opening, measurement of the geophysical properties, and granulometric, geochemical, mineralogical, and rockmagnetic analyses. These analyses are carried out on whole core sections, on split core surfaces, and on discrete samples (see Wilke et al., 2016) and are described in detail in several individual publications (Matzinger et al., 2007; Wagner et al., 2008a, b, 2009, 2012; Belmecheri et al., 2009, 2010; Holtvoeth et al., 2010, 2016; Leng et al., 2010; Lindhorst et al., 2010; Matter et al., 2010; Vogel et al., 2010a, b; Lacey et al., 2015, 2016; Francke et al., 2016; Just et al., 2016; Leicher et al., 2016). Dating of the sediment successions was mainly based on radiocarbon dating as well as tephrostratigraphic and tephrochronological work. Tuning of sediment proxies to orbital parameters, such as summer insolation and winter season length, or to other records has only been carried out on the sediment sequence from the DEEP site (Baumgarten et al., 2015; Francke et al., 2016; Zanchetta et al., 2016). Optical and geochemical information was used for a correlation of the DEEP core sequences and led to a composite profile of $584 \mathrm{~m}$ composite depth (mcd) (Francke et al., 2016, and unpublished data). Some of the sediment sequences were also studied for their fossil diatom, pollen, ostracod, or mollusc compositions. The sample preparation for the micro- and macrofossil analyses and the determination of the taxa are described in detail in the individual publications (Belmecheri et al., 2009, 2010; Wagner et al., 2009, 2014; Albrecht et al., 2010; Reed et al., 2010; Cvetkoska et al., 2016; Sadori et al., 2016; Zhang et al., 2016).

Information on interspecific relationships between Ohrid endemics and Balkan species, and on the drivers of speciation processes and community changes was derived from extant taxa by conducting molecular phylogenetic, lineagethrough-time plot, and diversification-rate analyses (for details see Föller et al., 2015, and references therein), as well as modelling of community assembly processes (see Hauffe et al., 2016).

\section{Results and discussion}

\subsection{Age and origin}

\subsubsection{Age}

At the start of the SCOPSCO project, the age and origin of Lake Ohrid were poorly constrained. Previous geological and biological age estimates varied from 2 to $10 \mathrm{Ma}$ (summarised in Albrecht and Wilke, 2008). Our new results allow for more precise age estimation. Based on SGR from borehole logging, MS from core logging, and total inorganic carbon (TIC) analyses on core catcher samples from the DEEP site, and by comparing these data with global climate records such as the benthic isotope stack LR04 (Lisiecki and Raymo, 2005), a minimum age of $1.2 \mathrm{Ma}$ has been proposed for the permanent lake phase of Lake Ohrid (Wagner et al., 2014). This minimum age is supported by the results from more detailed studies of the uppermost $247.8 \mathrm{mcd}$ of the DEEP site sequence, which covers the last $637 \mathrm{kyr}$, according to an age model derived from tephrochronology and tuning of biogeochemical proxy data to orbital parameters (Francke et al., 2016). The high-resolution data allow a better understanding of proxy variation over time and show that high TIC characterises interglacial periods and very low TIC represents glacial periods, as previously inferred from studies on core catcher material (Wagner et al., 2014). Indeed, a prominent TIC maximum at $\sim 368 \mathrm{~m}$ b.l.f. in the core catcher samples from the DEEP site was presumed to represent the Marine Isotope Stage (MIS) 31 at 1.081-1.062 Ma (Wagner et al., 2014), which is regarded as one of the warmest interglacials during the Middle Pleistocene Transition (MPT; e.g. Melles 
et al., 2012) between 1250 and $700 \mathrm{ka}$ (Clark et al., 2006). The lithology of the DEEP site sediment sequence indicates that lacustrine, hemipelagic sediments comprise the upper $\sim 430 \mathrm{~m}$ b.l.f., whereas littoral and fluvial sediments dominate below (Wagner et al., 2014). The transition from fluvial or littoral facies to hemipelagic sediments most likely indicates the onset of full lacustrine conditions in Lake Ohrid. Five TIC maxima below the presumed MIS 31 maximum and above the fluvial or littoral facies (see Wagner et al., 2014) could represent five additional interglacials, which would place the onset of hemipelagic sedimentation within MIS 41 and refines the minimum age of Lake Ohrid to ca. 1.3 Ma.

An age estimation for the onset of lacustrine sedimentation in the Lake Ohrid basin has been derived from comparing seismic and chronological information from core Co1202 recovered in the north-eastern part of the lake (Fig. 1). Tracking seismic reflectors from this coring location $(\sim 2 \mathrm{~km}$ from the DEEP site) to the central part of the lake allowed for the transfer of chronological information of the core into the basin centre (Lindhorst et al., 2015). In addition, the strength of the reflectors was correlated with chronological information and glacial-interglacial cycles derived from pollen analyses at Lake Ioannina (Tzedakis, 1994), $200 \mathrm{~km}$ to the south of Lake Ohrid. Based on this information, an average sedimentation rate of $0.43 \mathrm{~mm} \mathrm{yr}^{-1}$ was calculated for the last $450 \mathrm{kyr}$ in the basin centre (Lindhorst et al., 2015). Using this sedimentation rate for the maximum sediment fill of $\sim 800 \mathrm{~m}$ b.l.f. observed in the basin centre resulted in an age of 1.9 Ma for the onset of sedimentation (Lindhorst et al., 2015). At the DEEP site a somewhat lower average sedimentation rate of $0.39 \mathrm{~mm} \mathrm{yr}^{-1}$ can be calculated for the upper $247.8 \mathrm{mcd}$ or for the last $637 \mathrm{kyr}$ (Francke et al., 2016). Sediment compaction with increasing sediment depth (see Baumgarten et al., 2015) may have caused further lowering of the calculated sediment accumulation rate downward and also would lead to older ages compared to those based on a constant sedimentation rate of $0.43 \mathrm{~mm} \mathrm{yr}^{-1}$. However, lacustrine, hemipelagic sediments only form the upper $\sim 430 \mathrm{~m}$ b.l.f. of sediments at the DEEP site, which represents only half of the maximum sediment fill equivalent to $\sim 800 \mathrm{~m}$ b.l.f. As the underlying littoral and fluvial sediments most likely have significantly higher sedimentation rates, the extrapolated age of 1.9 Ma for the onset of hemipelagic sedimentation can be regarded as a tentative maximum age, assuming there were no major phases of erosion and/or nondeposition.

Overall, based on this new geological information, the minimum and maximum age of Lake Ohrid can be restricted to ca. 1.3 and 1.9 Ma, respectively. More precise age estimation will be obtained by ongoing tephrostratigraphic work and palaeomagnetic analyses, which may reveal the existence of major reversals in the Earth's magnetic field, such as the Jaramillo (1.075-0.991 Ma), Cobb Mountain (1.1938-1.1858 Ma), or Olduvai (1.968-1.781 Ma) subchrons (Nowaczyk et al., 2013, and references therein).
These estimates of 1.3-1.9 Ma correspond well to evolutionary data for endemic Lake Ohrid species obtained prior to the drilling campaign. Based on genetic information from extant endemic species and molecular-clock analyses, the onset of intralacustrine speciation in various groups of Lake Ohrid endemics ("ancient lake species flocks") started between 1.4 Ma for the limpet genus Acroloxus (Albrecht et al., 2006) and 2.0 Ma for the endemic Salmo trutta trout complex (Sušnik et al., 2006) and the Dina leech flock (Trajanovski et al., 2010). Assuming that the origin of Lake Ohrid predates the onset of intralacustrine speciation events, the latter authors suggested that the minimum age of Lake Ohrid is approximately $2.0 \mathrm{Ma}$. However, they were not able to explain why the species flocks investigated differed in their time of origination and why some of the flocks were as young as 1.3 Ma. A potential explanation is now provided by the initial results of the SCOPSCO deep drilling campaign, which indicate that persisting lacustrine conditions with pelagic or hemipelagic sedimentation established between 1.9 and 1.3 Ma ago. The period of lake establishment and persisting lacustrine conditions may have comprised up to several hundred thousand years, which in turn might have given rise to most species flocks in Lake Ohrid.

\subsubsection{Origin}

There is a broad consensus that the $40 \mathrm{~km}$ long and N-Strending Ohrid graben basin developed as part of the Alpine orogeny during a transtensional phase in the Late Miocene, followed by an extensional phase since the Pliocene (e.g. Cvijić, 1911; Aliaj et al., 2001; Dumurdzanov et al., 2004; Reicherter et al., 2011; Lindhorst et al., 2015). There is little consensus on the limnological origin of the lake itself, however. Albrecht and Wilke (2008) summarised four related hypotheses. Three of these hypotheses favour an origin as part of a marine ingression or a brackish-water lake system during the Miocene: the Mesohellenic Trough hypothesis, the Tethys hypothesis, and the Lake Pannon hypothesis. A fourth hypothesis postulates a de novo origin, i.e. that Lake Ohrid formed in a dry polje fed by springs during the Pliocene or Pleistocene. The latter is supported, in part, by the known existence of substantial active karst aquifers (Matzinger et al., 2006) and the seismic data, which indicate that Lake Ohrid formed in a relatively narrow and elongated valley (Lindhorst et al., 2015). Moreover, sediments at the base of the DEEP site sequence are formed by gravel, which is overlain by alternating peat layers, sand horizons, and fine-grained sediments, and contain a relatively shallow, obligate freshwater diatom flora (Wagner et al., 2014). These sediments indicate very dynamic environments, ranging from fluvial to slack water conditions, with varying shallow water conditions, and support, in combination with the presumed Pleistocene age of Lake Ohrid, the de novo hypothesis of lake formation. 


\subsection{Sediment architecture and basin development}

In addition to information on the formation of the Ohrid basin, the hydro-acoustic data sets from Lake Ohrid can also provide knowledge on mass transport deposits (MTDs) and on long-term lake-level change.

The evaluation of the seismic and hydro-acoustic data sets indicated that MTDs are only observed during the last ca. $340 \mathrm{ka}$ in Lake Ohrid (Lindhorst et al., 2016). Older MTDs are not covered by the seismic profiles or may be masked by multiple reflections below $250-300 \mathrm{~m}$ sediment depth in the central part of the basin. Five major MTDs are detected during MIS 9, 7, and 6. Since ca. $80 \mathrm{ka}$, the number of MTDs increased, but this is accompanied by a trend of decreasing MTD volume. Due to the restricted vertical resolution of the seismic data sets, the age control of the MTDs is relatively imprecise. Nevertheless, it seems that the occurrence of MTDs is not driven by or a response to glacialinterglacial cyclicity, as they occur during glacials, interglacials, and their respective transitions. Although MTDs are detected throughout the entire basin (Lindhorst et al., 2016), they cluster along the major faults in the south-eastern and north-western part of the basin and are probably the result of fault activity and major earthquakes (Lindhorst et al., 2012; Wagner et al., 2012). Hence, MTDs in the Ohrid basin apparently have a rather limited spatial extent and are not accompanied by basin-wide suspension clouds or turbidites. MTDs with a maximum thickness of $<3 \mathrm{~cm}$ are observed in the DEEP site record, with clusters in MIS 8, late MIS 6, and MIS 2 (Francke et al., 2016). The thickness of these MTDs is significantly below the vertical resolution of the seismic data.

The hydro-acoustic data can also provide information about the tectonic history of the basin with respect to lakelevel fluctuations. The minimum water depth can be estimated from measuring the depth difference of individual reflectors between their largest depth in the basins and the minimal depth of occurrence at the lake margins. The minimal depth of occurrence for individual reflectors may be a real reflection termination, but in most cases individual reflectors cannot be traced further up because the shallowest areas of the lake basin are not covered by the seismic and hydro-acoustic survey or reflectors could not be traced to the shallower parts due to faults (Fig. 2). In a second step, linking these reflectors to the chronological information from the DEEP site provides chronological information for the minimum water depth. Tracing a reflector from $\sim 275 \mathrm{~m}$ b.l.f. at the DEEP site, i.e. a reflector located below the existing age model, supposes a minimum water depth of $300 \mathrm{~m}$ (Fig. 2). Reflectors at the MIS 16/15 ( $\sim 240$ m b.l.f.) and the MIS13/12 boundaries ( $\sim 190$ m b.l.f.) suggest minimum water depths of $300 \mathrm{~m}$ as well, thus exceeding the present-day water depth of $293 \mathrm{~m}$ (Fig. 2). The minimum water depth was reduced to $225 \mathrm{~m}$ during MIS 9 ( $\sim 140 \mathrm{~m}$ b.l.f.), to $200 \mathrm{~m}$ during MIS 7 ( $100 \mathrm{~m}$ b.l.f.), and to $175 \mathrm{~m}$ during MIS 5
(47 m b.l.f.). In MIS 3 ( $20 \mathrm{~m}$ b.l.f.), the minimum water depth increased to $250 \mathrm{~m}$, returning to a level similar to that observed in the lower half of the record. Note that this method for estimating water depth contains several sources of uncertainties. The actual water depth during each period may have been much higher, as individual reflectors may continue to shallower water depths or even above the present lake level but cannot be mapped due to missing data coverage in shallow water depth, or reflectors may have been eroded during a following period of a lower lake level. Ongoing subsidence might also have affected the shape of the individual reflectors and potentially increased the maximum depth difference of individual reflectors. Nonetheless, the data suggest a general trend from deeper waters from prior to MIS 16 through to MIS 13/12, followed by decreasing water depths with a minimum in MIS 5 and a subsequent deepening to present-day lake level. As a result, the deepening of the Lake Ohrid basin was apparently not a continuous and gradational process; we assume that short- or mid-term changes reflect changes in water budgets while subsidence is a much slower process. However, already at or shortly after the end of the MPT at $700 \mathrm{ka}$ (Clark et al., 2006), the lake showed similar or even higher water depths compared to present lake level. The seismic data do indicate periods of very low lake levels or even a completely desiccated lake since that time.

Mapping of the hydro-acoustic reflectors indicates that the shape of the Ohrid basin slightly altered over time. Based on the isopleths, the deeper part of the basin changed from a more elongated shape to a roundish shape during the last ca. $700 \mathrm{kyr}$, with a formation of a secondary basin in the north-western part of the lake after the MIS 13/12 boundary at $478 \mathrm{ka}$ (Fig. 2). This also reflects the extension of the lake basin.

\subsection{Tephrostratigraphic and environmental history}

\subsubsection{Tephrostratigraphy}

The DEEP site sequence drilled in 2013 provides the most complete tephrostratigraphic record obtained from Lake Ohrid. A total of 39 tephra layers have been identified in the upper $247.8 \mathrm{mcd}$ so far (Fig. 3; Leicher et al., 2016, and unpublished data). Major element analyses (SEM-EDS/WDS; see Leicher et al., 2016, for details) on juvenile glass fragments suggest an origin exclusively from Italian volcanic provinces. Of these tephra layers (OH-DP-0027 to OH-DP2060), 13 could be identified and correlated with known and dated widespread eruptions (Leicher et al., 2016, and references therein). They include the Mercato tephra $(\mathrm{OH}-$ DP-0027, 8.43-8.63 cal ka BP) from Somma-Vesuvius, the Y-3 (OH-DP-0115, 26.68-29.42 cal ka BP), the Campanian Ignimbrite/Y-5 (OH-DP-0169, 39.6 $\pm 1.6 \mathrm{ka})$ and the X-6 (OH-DP-0404, 109 $\pm 2 \mathrm{ka}$ ) from the Campanian volcanoes, the P-11 (OH-DP-0499, 129 $\pm 6 \mathrm{ka}$ ) from Pantelleria, the Vico B (OH-DP-0617, $162 \pm 6 \mathrm{ka}$ ) from the Vico volcano, 


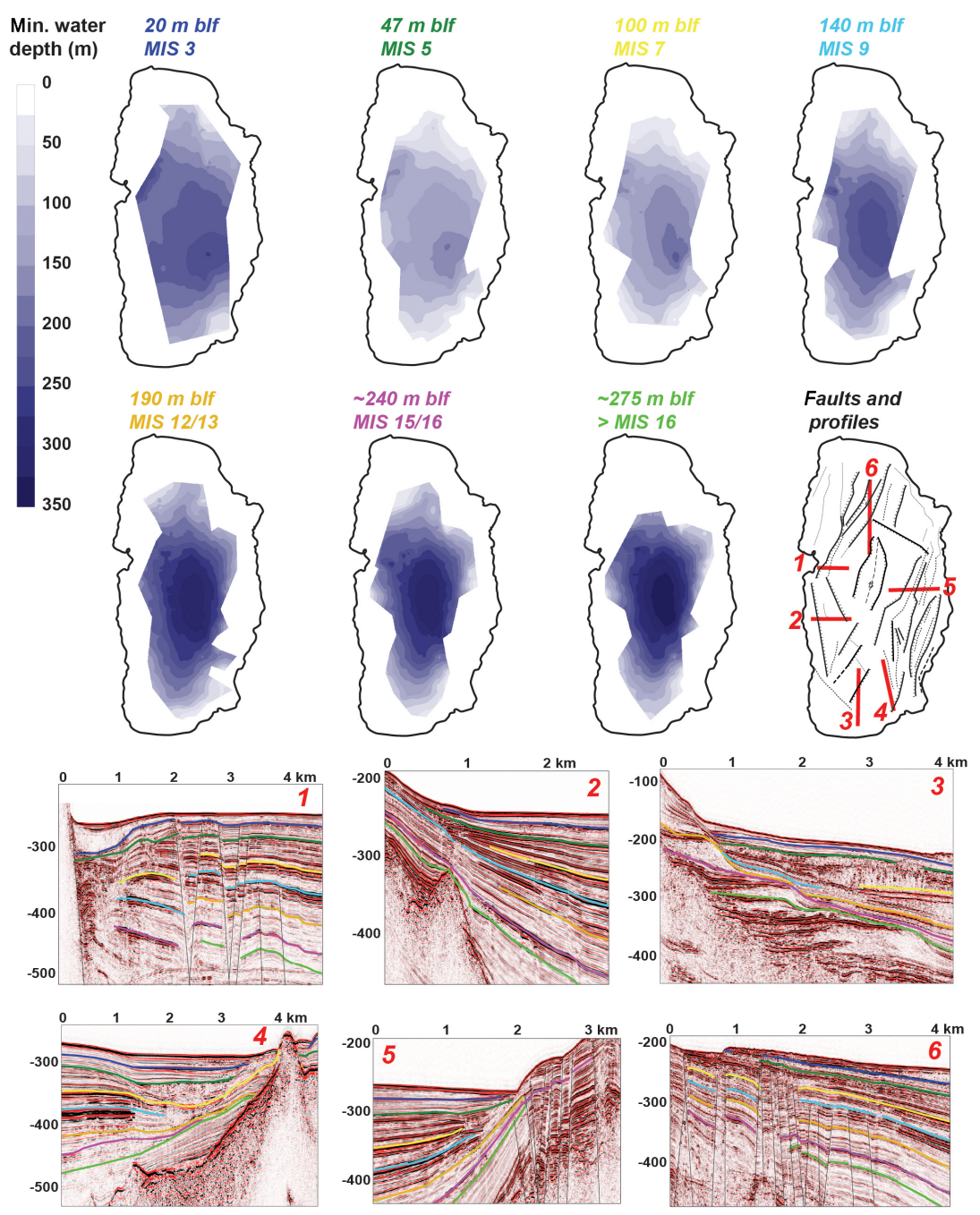

Figure 2. Selected seismic profiles and calculated water depths at different times (see text for details). The arrow of the reflector at $140 \mathrm{~m}$ b.l.f. (MIS 8/9) indicates the existence of a secondary basin in the north-western part of the lake. Please note that the lake was probably larger for most periods but individual reflectors cannot be traced to the shallower water depth due to faults. This also explains why the estimated water depth is not zero at the edges of the shown lake coverage.

the Pozzolane Rosse (OH-DP-1817, $457 \pm 2 \mathrm{ka})$ and the Tufo di Bagni Albule (OH-DP-2060, 527 $\pm 2 \mathrm{ka}$ ) from the Colli Albani volcanic district, and the Fall A (OH-DP$2010,496 \pm 3 \mathrm{ka})$ from the Sabatini volcanic field. Furthermore, a comparison of the Ohrid record with tephrostratigraphic records of mid-distal Mediterranean archives enabled the identification of less-well-known tephra layers, such as the TM24-a/POP2 (OH-DP-0404, $101.8 \mathrm{ka}$; Regattieri et al., 2015) from Lago Grande di Monticchio and the Sulmona basin, the SC5 (OH-DP-1955, 493.1 $\pm 10.9 \mathrm{ka})$ from the Mercure basin, and the A11/12 (OH-DP-2017, $511 \pm 6 \mathrm{ka})$ from the Acerno basin, whose specific volcanic sources are still poorly constrained. OH-DP-0624 was tentatively correlated with the CF-V5/PRAD3225 layers from the Campo Felice basin/Adriatic Sea and thus to the Pitigliano Tuff from the Vulsini volcanic field (ca. $163 \mathrm{ka}$; Leicher et al., 2016). However, recent tephrochronological results including ${ }^{40} \mathrm{Ar} /{ }^{39} \mathrm{Ar}$ of a tephra from the Fucino basin, central Italy, suggest that these tephras correspond to an un-known eruption from the Neapolitan volcanic area at $158.8 \pm 3.0 \mathrm{ka}$ (Giaccio et al., 2017). In order to obtain a consistent set of ages all ${ }^{40} \mathrm{Ar} /{ }^{39} \mathrm{Ar}$ were calculated by using the same flux standard (1.194 Ma for Alder Creek sanidine, which corresponds to Fish Canyon sanidine at 28.02 Ma). The chronological information of 11 of the well-identified tephras from Lake Ohrid was used as first-order tie points for the agedepth model of the composite core, and complemented by tuning of sediment proxies to orbital parameters, such as summer insolation and winter season length (Francke et al., 2016).

Fifteen additional tephra horizons have been identified within the lower hemipelagic section of the DEEP 

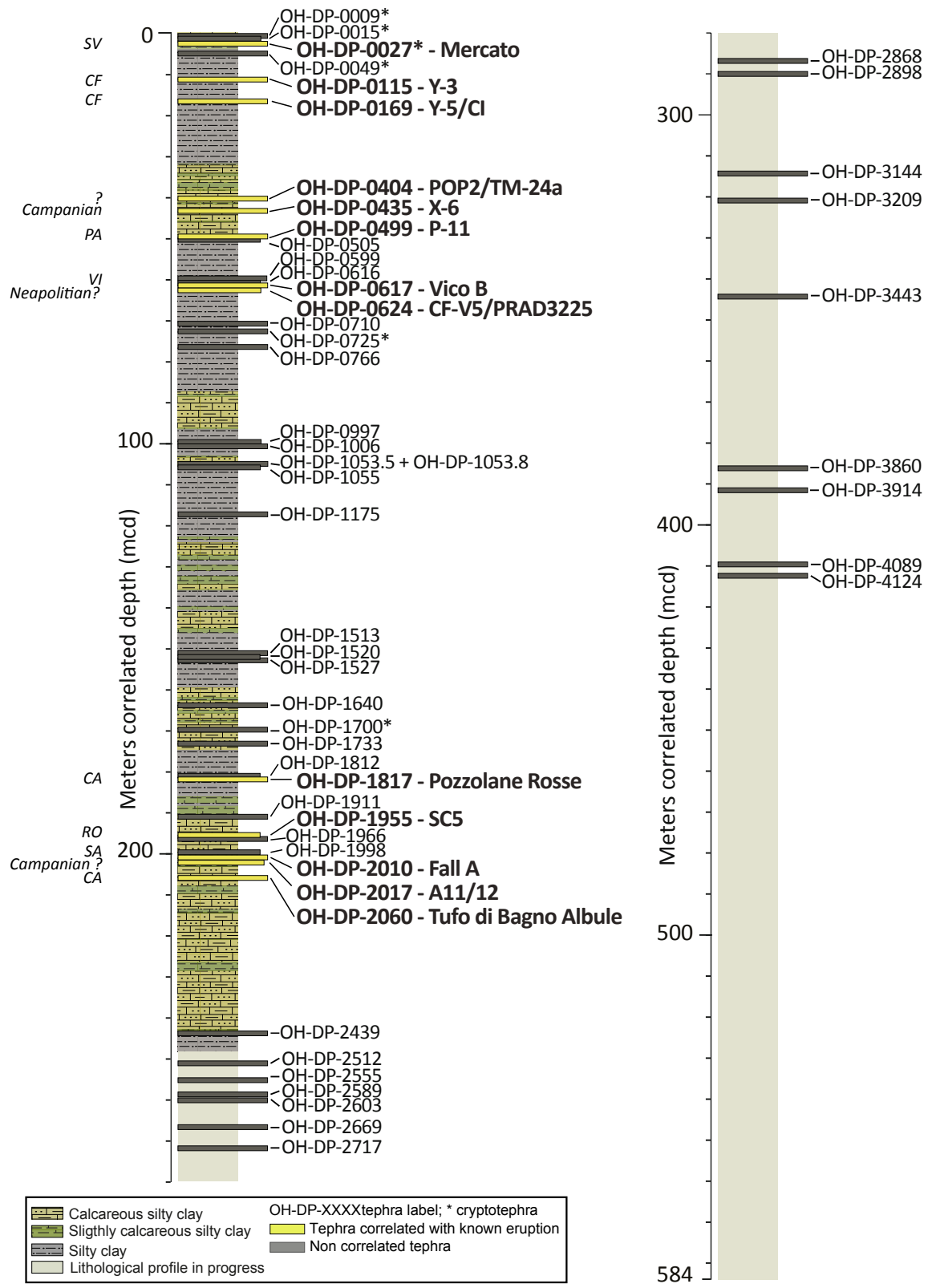

Figure 3. Lithostratigraphy of the upper $247.8 \mathrm{mcd}$ and tephra and cryptotephra horizons in the DEEP sediment sequence. For nomenclature and details see Leicher et al. (2016). Tephra in bold was used as tie points for the age-depth model for the upper 247.8 mcd spanning the last 637 kyr (Francke et al., 2016; Leicher et al., 2016). Tephrostratigraphic work on tephra from below 247.8 mcd is ongoing.

site sequence between 248 and $450 \mathrm{mcd}$ (Fig. 3) and are the subject of ongoing work. Although knowledge of tephrostratigraphy for the period $>637 \mathrm{ka}$ is restricted, a combination of tephrochronological with palaeomagnetic information should provide a robust chronology for this part of the sequence.

With a total of at least 54 tephra layers intercalated in a continuous sediment succession of $>1.3 \mathrm{Ma}$, the tephrostratigraphic record from Lake Ohrid is a strong candidate to become the template for central Mediter- ranean tephrostratigraphy, especially for the poorly known and explored Lower and Middle Pleistocene periods. The tephrostratigraphic record may also help to allow reevaluation and improvement of the chronology of dated and undated tephra layers from other key sites, such as the age of the Fall A tephra (Leicher et al., 2016). Moreover, the tephras constitute valuable independent tie points that resolve leads and lags between changes in different components of the climate system and allow a synchronisation of the Lake Ohrid record with other regional records (Zanchetta et al., 2016). 


\subsubsection{Environmental history}

The examination of the environmental history of Lake Ohrid over the last $637 \mathrm{kyr}$ focuses both on long-term changes over several glacial-interglacial periods and short-term changes on the sub-orbital scale.

\section{Long-term changes}

The study of the long-term environmental history of Lake Ohrid and its surrounding area includes the reconstruction of minimum lake levels based on hydro-acoustic information, by vegetation changes in the catchment, and by internal lake proxies. According to the established age model (Francke et al., 2016), hydro-acoustic data (Lindhorst et al., 2015), and borehole logging data (Baumgarten et al., 2015), the sediments deposited at $637 \mathrm{ka}$ are now located $\sim 240 \mathrm{mb}$ b.l.f. at the DEEP site. If the altitude of the Lake Ohrid outlet or the bedrock gap used by the river Crni Drim would have been the same as it is today (693.5 ma.s.1.), the water depth of Lake Ohrid at $637 \mathrm{ka}$ would have been more than $480 \mathrm{~m}$. There is no evidence in the seismic or sedimentological data for such a great water depth at that time, which implies that subsidence or other tectonic activity affected the sediment succession in the lake basin or the altitude of the outlet. Nevertheless, the hydro-acoustic data suggest a fairly deep lake at the end of the MPT, with a water depth similar or even deeper than today (Figs. 2 and 4). Shallower minimum water depths are tentatively indicated between MIS 9 and MIS 3, with an absolute minimum during MIS 6 or MIS 5. Tectonic activity and the relative altitude of the outlet are probably the most significant contributors to water-depth variations in Lake Ohrid. A comparison of the minimum water-depth data with pollen data shows some differences but suggests that climate change may also have triggered water-depth fluctuations. Although the Lake Ohrid watershed was a refugial area for both temperate and montane trees during the glacial periods of the last $500 \mathrm{kyr}$, high amounts of herbs (grasses, chenopods, Cichorioideae, and Cyperaceae) are found in the earlier glacials MIS 12, MIS 10, and MIS 8 and indicate the presence of open formations and grassland (Sadori et al., 2016). Such vegetation requires relatively humid conditions, whereas steppe vegetation with unexpected high amounts of Artemisia and pioneer taxa typical of dry conditions dominated during MIS 6, MIS 4, and MIS 2 (Fig. 4; Sadori et al., 2016). The pollen data suggest that in addition to glacials, a drying trend is also observed in interglacials. This is mainly based on the reduction of montane trees, particularly Abies and Picea values in MIS 5 and the Holocene (Sadori et al., 2016), which may indicate a rearrangement of vegetation in altitudinal belts. The overall progressive change from cooler and wetter conditions recorded during both interglacial and glacial periods prior to $288 \mathrm{ka}$ to subsequently warmer and drier interglacials and glacials (Sadori et al., 2016) broadly matches with the generally shallower minimum water levels reconstructed by tracing hydro-acoustic reflectors throughout the basin. Moreover, driest conditions and a maximum in steppe vegetation between 160 and $129 \mathrm{ka}$ (Sadori et al., 2016) correspond to a prominent lake-level lowstand and the formation of a subaquatic terrace $\sim 60 \mathrm{~m}$ below the present lake level in the north-eastern Ohrid basin (Fig. 4; Lindhorst et al., 2010). This lowstand was reconstructed based on hydro-acoustic studies and tephrochronological information from two short sediment cores. Two tephras deposited on the terrace were previously correlated with MIS 5 tephras C-20 (ca. $80 \mathrm{ka}$ ) and X5 (105 $\pm 2 \mathrm{ka}$ ) (Sulpizio et al., 2010), and it was supposed that the formation of this terrace took place during MIS 6 (Lindhorst et al., 2010). However, new tephrostratigraphic results suggest that the two tephras instead correspond with Vico B (OH-DP-0617, $162 \pm 6 \mathrm{ka})$ and CF-V5/PRAD3225 (OH-DP-0624, ca. 163 ka; Leicher et al., 2016). This constrains the formation of this terrace to the earlier part of MIS 6 and the subsequent lake-level increase to late MIS 6 or early MIS 5, with a secondary lowstand around $100 \mathrm{ka}$ (Fig. 4). The lake-level curve from northeastern Lake Ohrid is only partly in phase with the minimum lake-level curve based on the new hydro-acoustic reconstruction (Figs. 2 and 4). Whereas the terraces in the north-eastern basin provide relatively precise water depths, the reconstruction based on hydro-acoustic information (Fig. 2) can give only minimum water depths and is certainly biased by subsidence.

Internal lake proxies support the long-term trend seen in pollen from generally wetter and cooler interglacial and glacial periods between $637 \mathrm{ka}$ and ca. $300 \mathrm{ka}$ to drier and warmer stages between $300 \mathrm{ka}$ and the present. The oxygen isotope composition of lake water $\left(\delta^{18} \mathrm{O}_{\text {lakewater }}\right)$, calculated from $\delta^{18} \mathrm{O}$ of endogenic calcite, shows only moderate variability between interglacial periods with a relatively stable climate from MIS 15 to MIS 13, progressively wetter conditions during MIS 11 and MIS 9, and increasingly evaporated, drier conditions in more recent interglacials (Fig. 4; Lacey et al., 2016). In particular, higher $\delta^{18} \mathrm{O}_{\text {lakewater }}$ through MIS 5 and the Holocene indicates higher evaporation due to dry and warm conditions prevailing under a Mediterranean-type climate. During glacials calcite is typically absent, but $\delta^{18} \mathrm{O}_{\text {lakewater reconstructed from early diage- }}$ netic siderite shows a more pronounced long-term shift, with values being consistent with the adjacent interglacials during MIS 14, MIS 12, and MIS 10, a transition to lower values

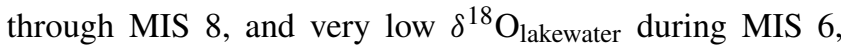
MIS 4, and MIS 2 (Fig. 4). The similarity between interglacial and glacial lake water prior to ca. $300 \mathrm{ka}$ suggests that Lake Ohrid may have experienced regular and complete mixing, as calcite and siderite form in different environments calcite in surface waters during summer months and siderite as a product of early diagenesis in the surface sediments. Lower average $\delta^{18} \mathrm{O}_{\text {lakewater }}$ before ca. $300 \mathrm{ka}$ indicates moderate summer temperatures (reduced seasonality). It may also suggest higher activity of the karst system due to more pre- 


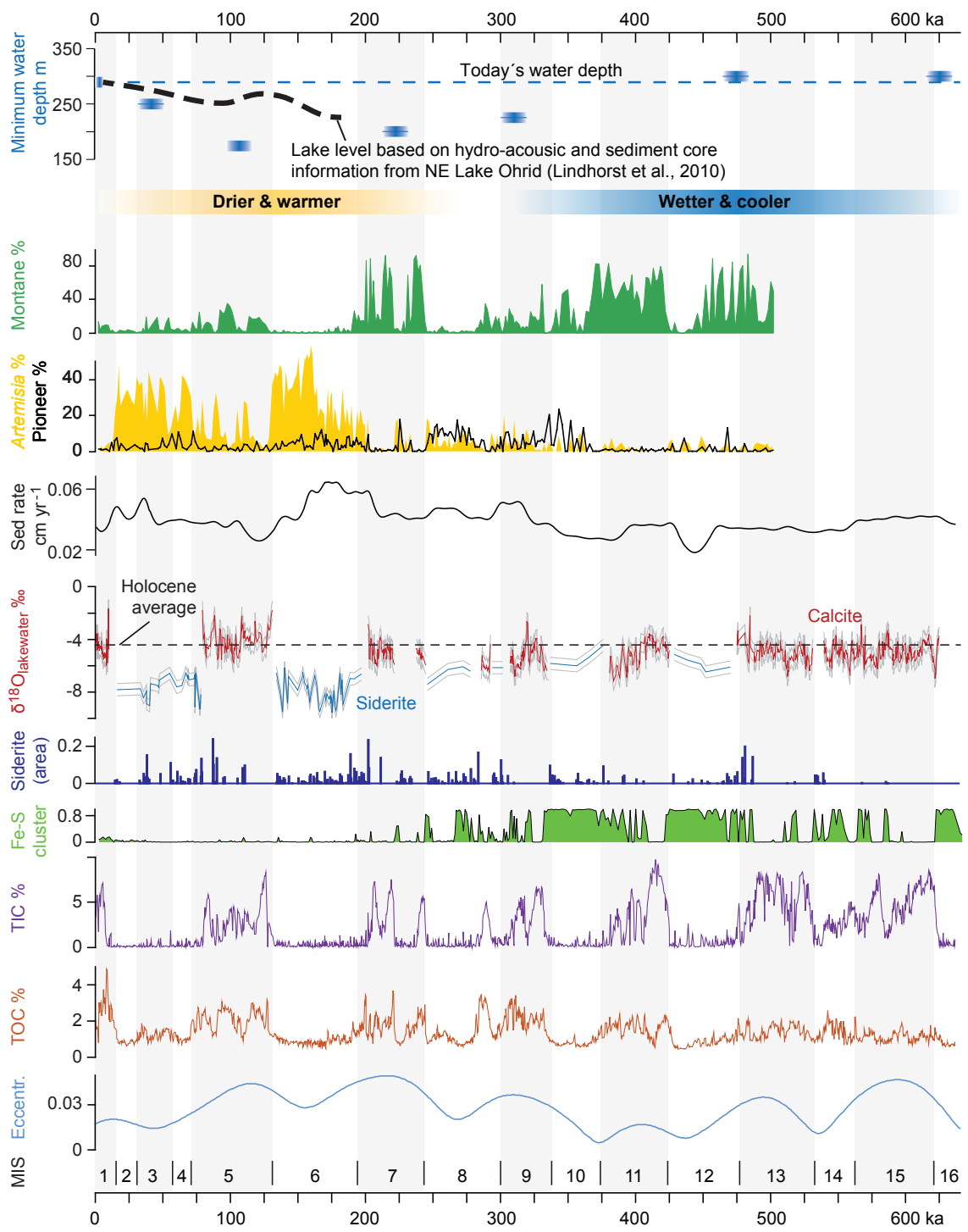

Figure 4. Lake-level reconstructions (modified from Lindhorst et al., 2010; for details see Sect. 4.3.2 of this study), pollen (Sadori et al., 2016), sedimentological, and geochemical data over the last $637 \mathrm{kyr}$ (Francke et al., 2016; Just et al., 2016; Lacey et al., 2016) indicate a long-term shift from cooler and wetter to drier and warmer glacial and interglacial periods around 300 ka. Pollen curves have been corrected with respect to those reported in Sadori et al. (2016). MIS boundaries are according to Lisiecki and Raymo (2005).

cipitation and/or a higher lake level of neighbouring Lake Prespa. Subsequently, a trend to higher $\delta^{18} \mathrm{O}_{\text {lakewater }}$ during interglacials indicates stronger rates of summer evaporation and drier conditions, and lower $\delta^{18} \mathrm{O}_{\text {lakewater }}$ in glacial periods suggests isotopically fresh conditions most likely due to low evaporation. Increasing summer aridity towards present is also backed by the gradual increase of Mediterranean taxa pollen percentages.

A transition from generally wetter and cooler to drier and warmer conditions is also indicated by a shift from relatively invariant and low total organic carbon (TOC) prior to ca. $300 \mathrm{ka}$ towards more fluctuating and higher TOC, particularly during the more recent interglacials (Fig. 4; Francke et al., 2016). Wetter and cooler conditions after the MPT drive a high activity of the karst system and intense mixing of the water column, thus promoting decomposition of organic matter. This would, in turn, increase the supply of sulfur to the sediments and allow for the formation of greigite (Fig. 4; Just et al., 2016). A greater activity of the karst system and associated high ion $\left(\mathrm{Ca}^{2+}, \mathrm{HCO}_{3}^{-}\right)$input is further supported by the relatively high TIC during MIS 15, MIS 14, and MIS 13 (Fig. 4; Francke et al., 2016). Pollen data suggest moderate summer temperatures, i.e. conditions that would have favoured mixing and, hence, increased organic matter degradation. Conversely, drier and warmer conditions after ca. 320 ka likely reduced mixing of the water column during 
the interglacials, which would lead to anoxic bottom waters and a better preservation of organic matter. Just et al. (2016) proposed a decrease in sulfide availability, either by lower sulfate concentration in lake water or ceased upward migrating fluids, changing the geochemical regime in Lake Ohrid. Such conditions are indicated by a shift from predominant glacial formation of Fe sulfides to siderite around $320 \mathrm{ka}$, when higher Fe concentrations and limited sulfur content of sediments may have prevented the formation of greigite (Fig. 4; Just et al., 2016).

The maximum sedimentation rate during early MIS 6 (Francke et al., 2016) correlates well with the formation of the subaquatic terrace located at $60 \mathrm{~m}$ below the present lake level (Fig. 4; Lindhorst et al., 2010). The lower lake level during early MIS 6 led to exposure and erosion of formerly shallow parts of the lake and a lower distance from inlets to the central part of the lake. However, there is no indication, e.g. in isotope or redox sensitive data, for an endorheic lake at that time or any other time during the last $637 \mathrm{kyr}$. It thus seems that the outlet was active most of the time and climate driven lake-level change may have existed only for relatively short periods or has been compensated at least partly by tectonic activity. Significant variations in TOC and isotope data during early MIS 6 imply a higher variability of the climate compared to the latter period of MIS 6 (Fig. 4). These observations correspond well with palynological studies from the Ioannina basin, where distinct vegetation changes between 185 and $155 \mathrm{ka}$ indicate a high climate variability, whereas a greater abundance of steppe taxa and other herbaceous elements, combined with lower tree pollen percentages, during the latter MIS 6 after $155 \mathrm{ka}$ indicates that the landscape was predominantly open in character and more stable (Roucoux et al., 2011).

\section{Sub-orbital changes}

On a sub-orbital scale, prominent environmental changes in the Northern Hemisphere that potentially affected Lake Ohrid include Dansgaard-Oeschger (D/O) and Heinrich events (HE) (e.g. Bond et al., 1992, 1993; Dansgaard et al., 1993; Raymo et al., 1998; McManus et al., 1999). D/O events are a pervasive feature of the last glacial (e.g. Wolff et al., 2010) and also of older glacial periods (Stein et al., 2009; Naafs et al., 2014). They are likely related to variations in the Atlantic Meridional Overturning Circulation (AMOC) and are recorded as climatic perturbations in many marine and terrestrial records (e.g. Genty et al., 2003; Rohling et al., 2003; Margari et al., 2009; Fletcher et al., 2013; Naafs et al., 2014; Seierstad et al., 2014; Stockhecke et al., 2016). In the eastern Mediterranean, D/O events may have influenced regional hydrology and led to large-scale droughts during the past four glacial cycles (Stockhecke et al., 2016). HE are distinctively represented by deposition of ice-rafted debris (IRD) in North Atlantic marine cores (e.g. Hemming, 2004) and are also well documented to have had an imprint on ma- rine and terrestrial records for the last glacial and beyond (e.g. Shackleton et al., 2000; Roucoux et al., 2001, 2011; Sanchez-Goni et al., 2002; Martrat et al., 2004; Margari et al., 2010; Naafs et al., 2013). At the IODP drill site U1308 in the North Atlantic, HE are first indicated during MIS 16 and are represented by IRD layers that are rich in detrital carbonate and poor in biogenic carbonate (Hodell et al., 2008). It has been speculated that ice volume and the duration of glacial conditions surpassed a critical threshold during MIS 16 and activated the dynamic processes responsible for Laurentide Ice Sheet instability in the region of Hudson Strait, which led to increased iceberg discharge and weakening of thermohaline circulation in the North Atlantic (Hodell et al., 2008).

MIS 12 is considered to be one of the most severe glacials during the Quaternary, with the lowest summer sea surface temperatures (SSTs) recorded across multiple records (e.g. Shackleton, 1987; Naafs et al., 2013, 2014; Rohling et al., 2014). Abrupt sea surface warming events of $3-6^{\circ} \mathrm{C}$ in the midlatitude North Atlantic during MIS 12 likely reflect the imprint of D/O events and probably had a substantial impact on global climate (Naafs et al., 2014). In contrast to the observations from MIS 16, a temporal lag between the occurrence of IRD and surface water cooling during MIS $12 \mathrm{im}$ plies that HE were not the cause for a weakening of the thermohaline circulation in the North Atlantic at this time (Naafs et al., 2014).

High-resolution records from the Mediterranean region, which can be used to test a larger regional or even global impact of D/O and HE during MIS 16 or MIS 12, are scarce (e.g. Hughes et al., 2006; Tzedakis et al., 2006; Girone et al., 2013; Capotondi et al., 2016). A multi-proxy record with lithological, geochemical, and isotope data from the Sulmona basin in central Italy covering MIS 12 shows pronounced hydrological variability at orbital and millennial timescales, which replicates North Atlantic and western Mediterranean SST fluctuations (Fig. 5; Regattieri et al., 2016). Several short-term fluctuations in the MIS 12 Sulmona record most likely reflect sub-orbital-scale hydrological variations and are apparently related to reduced precipitation sourcing from the North Atlantic due to episodes of iceberg melting and IRD deposition at the west Iberian margin (Regattieri et al., 2016, and references therein). However, as the timing of these IRD events at the western Iberian margin was used to improve the chronology of the Sulmona record, the correlation of hydrological variations in central Italy and IRD deposition in the North Atlantic is not fully independent.

At Lake Ohrid and further to the east, the arboreal pollen concentration in the Tenaghi Philippon record from Greece correlates well with the general pattern of the SSTs in the North Atlantic during MIS 12 (Fig. 5; Tzedakis et al., 2006). The resolution of the existing record is too low yet to allow a clear identification of $\mathrm{D} / \mathrm{O}$ or $\mathrm{HE}$ related climate change. The high-resolution record from Lake Van in eastern Turkey also cannot be used for testing the climatic impact of D/O or HE on the eastern Mediterranean, as the sediments of MIS 12 


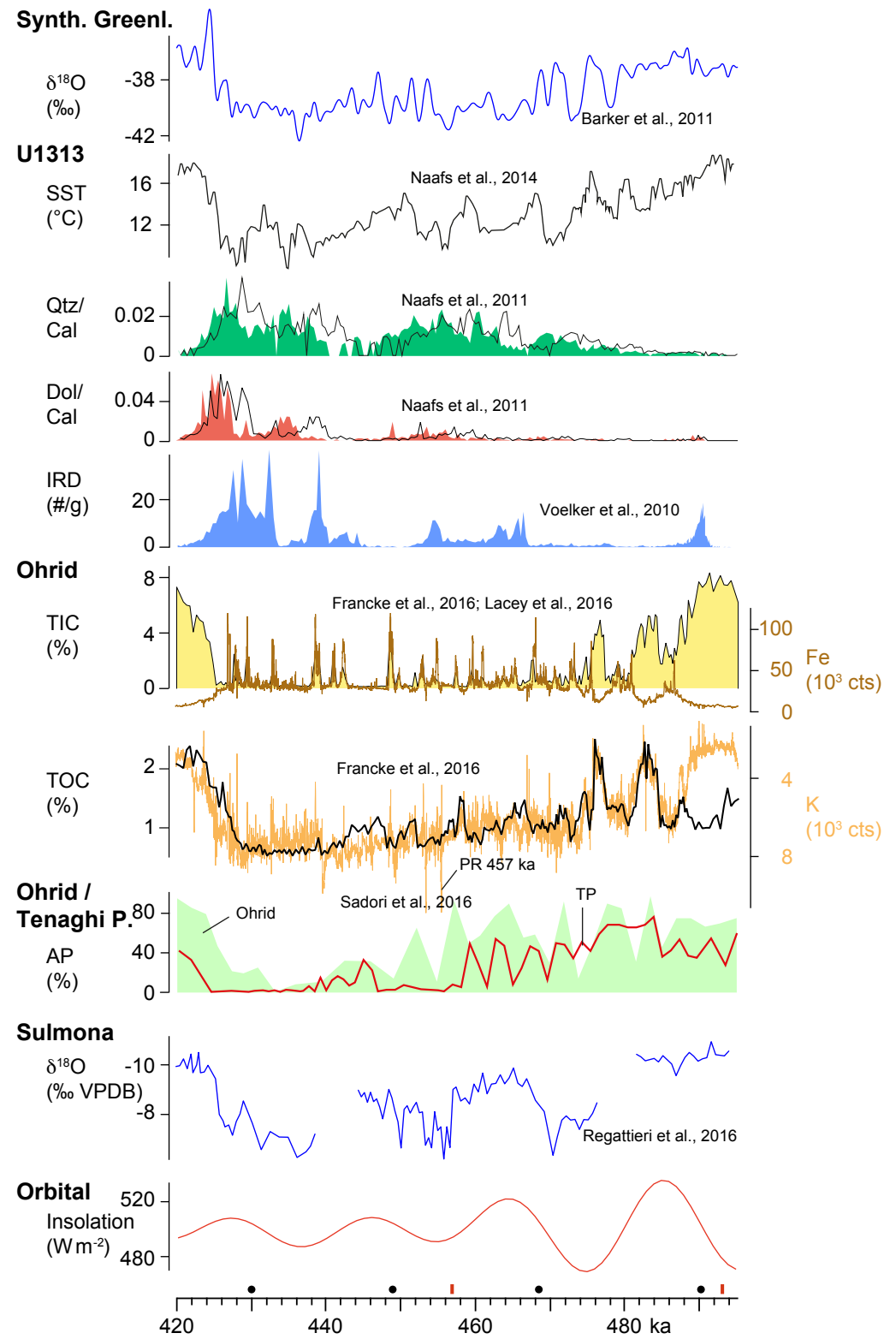

Figure 5. Geochemical data from the DEEP site sequence with sub-orbital changes during MIS 12 in comparison with other records from a similar latitude (for location of North Atlantic core U1313, the pollen record from Tenaghi Philippon, and the isotope record from Sulmona basin see Fig. 1). Arboreal pollen (AP) records are excluded of Pinus, Juniperus, and Betula (Sadori et al., 2016); the record from Tenaghi Philippon is based on pollen data from Wijmstra (1969) and Wijmstra and Smit (1976) and the age model from Tzedakis et al. (2006) (see also Sadori et al., 2016). Red bars and black dots at the bottom age axis indicate tephrochronological tie points and tuning points used for the age model of the DEEP site sequence (Francke et al., 2016).

and the onset of MIS 11 are disturbed and lack independent age control (Stockhecke et al., 2014).

The new high-resolution record from the DEEP site in Lake Ohrid now offers the possibility to assess the impact of D/O or HE during MIS 12 on a broader regional scale, particularly as it provides two absolute tephra age control points with ages centred at $493.1 \pm 10.9$ and $457 \pm 2 \mathrm{ka}$ (Fig. 5; Francke et al., 2016; Leicher et al., 2016). During MIS 12, potassium $(\mathrm{K})$ shows a long-term increase, which supports the overall trend towards colder temperatures, such as can be inferred from other marine, terrestrial, or synthetic climate records (Fig. 5). K represents the proportion of clastic, terrigenous matter relative to the content of carbonate (reflected by TIC) and organic matter (reflected by TOC and $\mathrm{bSi}$ ). TOC was used to infer the severity of glacials at Lake Ohrid (Francke et al., 2016) and shows a remark- 
able saw tooth pattern during MIS 12, which resembles fluctuations in SST related to D/O variability from the North Atlantic marine record U1313 (Fig. 5; Naafs et al., 2014). Higher TOC is favoured by both increased overall productivity (on land and in the water column) as well as increased organic matter preservation, with the latter resulting from oxygen depletion of the bottom water due to enhanced thermal stratification, decreased mixing, and higher temperatures. These higher temperatures at Lake Ohrid likely correlate with higher SSTs in the North Atlantic. The TOC record from Lake Ohrid thus would be the first terrestrial record to indicate $\mathrm{D} / \mathrm{O}$ cycle-related teleconnections between the North Atlantic thermohaline circulation and the climate in the north-eastern Mediterranean region during MIS 12. Interestingly, the dominant Pinus pollen abundance in the vegetation record indicates a regular $\sim 8 \mathrm{kyr}$ variability during MIS 12 and 10, for which a high-resolution analysis is now being performed (Fig. 2 in Sadori et al., 2016).

The environmental impact of HE or other short-term climate events has been studied in detail for the last glacial cycle in several records from the Balkans (e.g. Tzedakis et al., 2004; Müller et al., 2011). Based on pollen and diatom analyses from lakes Prespa and Ohrid, HE in the North Atlantic during MIS 4 to MIS 2 led to short spells of very dry and cold conditions superimposed on the glacial conditions (Panagiotopoulos et al., 2014; Cvetkoska et al., 2015). Moreover, there is an increased formation of Fe and Mn concretions in Lake Prespa sediments, most likely driven by a significant shift in the bottom water redox conditions (Wagner et al., 2010). According to diatom studies spanning the last $92 \mathrm{ka}$, Lake Prespa experienced significant regime shifts that are correlated with lake-level fluctuations and changes between (oligo-) meso- and eutrophic conditions (Cvetkoska et al., 2016). Lake Ohrid seems to be less sensitive to shortterm climate change due to its higher volume-to-surface area ratio (e.g. Wagner et al., 2010; Leng et al., 2013). It does not indicate sub-orbital timescale lake-level changes and shifted between ultra oligo- and oligotrophic conditions during the last $92 \mathrm{kyr}$ (Cvetkoska et al., 2016). However, the formation of $\mathrm{Fe}$ and $\mathrm{Mn}$ concretions and the occurrence of siderite indicate that Lake Ohrid is also sensitive to shifts in the bottom water redox conditions (Lacey et al., 2016). During MIS 12, $\mathrm{Fe}$ peaks in X-ray fluorescence data are positively correlated with TIC and indicate the formation of early-diagenetic siderite in response to a shift in bottom water redox conditions towards a more oxic environment (Fig. 5; Francke et al., 2016; Lacey et al., 2016). The Fe peaks during the coldest period of this glacial match particularly well with the number of IRD grains and with maxima in the quartzite-calcite or dolomite-calcite ratio in the U1313 record from the North Atlantic (Fig. 5). The latter are interpreted as millennial icerafting-driven events (Voelker et al., 2010; Naafs et al., 2011, 2013) and thus demonstrate that North Atlantic HE may have caused changes in internal lake conditions, such as bottom water redox conditions.
One of the HE, the $\mathrm{H} 4$ event at $40.4-38.4 \mathrm{ka}$, is superimposed by another short-term event: the eruption from the Campi Flegrei volcanoes $(39.6 \pm 1.6 \mathrm{ka})$. This eruption is one of the most severe volcanic eruptions during the Pleistocene and left a $15 \mathrm{~cm}$ thick tephra known as Campanian Ignimbrite or Y-5 marine tephra layer in the records from lakes Ohrid and Prespa (e.g. Wagner et al., 2009; Vogel et al., 2010b; Damaschke et al., 2013). High-resolution studies of diatoms in both lake sediment records indicate little evidence for a response of the diatom community related to the $\mathrm{H} 4$ event, but they do show a clear and rapid change following tephra deposition (Jovanovska et al., 2016). This strong change is likely due to fertilisation and the availability of nutrients, particularly silica, such as it was shown in laboratory studies and leaching experiments of tephra with Lake Ohrid water (D'Addabbo et al., 2015). After the initial response, diatom community compositions in lakes Ohrid and Prespa returned to their quasi pre-disturbance state. In Lake Ohrid, the recovery time was ca. 1100 years vs. ca. 4000 years in Lake Prespa (Jovanovska et al., 2016). Although both lakes are resilient to short-term environmental change, it seems that Lake Ohrid is even more resilient than Lake Prespa, likely due to differences in geology, lake age, limnology, and intrinsic parameters of the diatom proxies (Jovanovska et al., 2016).

\subsection{Drivers of biodiversity change}

One of the major interdisciplinary goals of the SCOPSCO project is to infer the drivers of the extraordinary endemic biodiversity in Lake Ohrid, in general, and to evaluate the influence of major environmental events on evolutionary processes, in particular. Lake Ohrid thus serves as a model system to address questions that have puzzled evolutionary biologists for decades. These questions include the problem whether the high number of endemic species is mainly a result of an accumulation of relict species ("reservoir function") and/or of a high rate of intralacustrine speciation ("cradle function"). Moreover, if intralacustrine speciation plays a significant role, is it primarily driven by geographic or environmental gradients during periods of relatively constant environmental conditions, possibly supported by a high ecosystem resilience of the lake, or does ongoing environmental change lead to an increase (or decrease) in rates of species diversification? Finally, what role do potentially "catastrophic" environmental fluctuations play, such as lake-level change or significant changes in the trophic state? 


\subsubsection{Reservoir vs. cradle function of Lake Ohrid}

As discussed in Föller et al. (2015), ancient lakes have often been considered to serve as evolutionary or geographic refugia, either harbouring old and distinct lineages or enabling the accumulation of species from extralimital areas during periods of adverse environmental changes, respectively (reservoir function). However, previous evolutionary studies in Lake Ohrid on selected animal taxa could not demonstrate the existence of such relict species (sensu Grandcolas et al., 2014) because either ancestral distribution ranges are largely unknown (e.g. Schultheiß et al., 2008) or the native species are not extraordinarily old (e.g. Albrecht et al., 2008; Hauswald et al., 2008). Instead, intralacustrine speciation after immigration events prevails. Most endemic animal species in Lake Ohrid are considerably younger than the lake itself and form monophyletic clades (also see Sect. 4.1.2). This suggests that the high endemic species richness in Lake Ohrid invertebrates is predominantly a result of intralacustrine diversification (cradle function; e.g. Albrecht et al., 2006, 2008; Wilke et al., 2007; Schultheiß et al., 2008; Wysocka et al., 2014; Föller et al., 2015).

Interestingly, the situation is different for plant species inhabiting the surrounding of Lake Ohrid. For example, the existing pollen record from the DEEP site sequence, which covers the last $500 \mathrm{kyr}$, indicates that the Lake Ohrid catchment has indeed been a refugial area for both temperate and montane trees during glacial periods (Sadori et al., 2016), comparable to the Lake Ioannina catchment (Tzedakis et al., 2002).

\subsubsection{Impact of environmental change on species diversification}

Ancient lakes are often considered to be comparatively stable systems, potentially resulting in constant diversification rates (i.e. speciation minus extinction rates) over time. Nonetheless, several factors, often related to environmental, geological, or climatic changes, and depending on the genetic features of the species, have been suggested to affect the tempo of diversification in ancient lake species flocks. Accordingly, phases of rapid environmental fluctuations may lead to net evolutionary change. Diversification rates may be higher in the initial phase of lake colonisation and may decline once niche space is increasingly occupied. Alternately, there might be a pronounced lag phase between the colonisation of a lake and the onset of subsequent diversification (reviewed in Föller et al., 2015).

Although high-resolution sediment-core analyses, covering the last $637 \mathrm{kyr}$, indicate that Lake Ohrid experienced several environmental changes, phylogenetic studies on a microgastropod group using lineage-through-time plots and diversification-rate analyses did not reveal significant changes in this rate over time (Föller et al., 2015). Moreover, diatom community analyses conducted from the DEEP sed- iment cores could not show extinction events due to major environmental events such as tephra deposition (Jovanovska et al., 2016; for details see Sect. 4.3.2) and climate change over the last $92 \mathrm{kyr}$ (Cvetkoska et al., 2016). However, the potential for a regime shift increases with recent human impact on the diatom flora of both lakes Ohrid (Zhang et al., 2016) and Prespa (Cvetkoska et al., 2015) although, again, Ohrid appears to be more well-buffered from eutrophication than Prespa.

The reasons for the relatively constant diversification rate over time observed in microgastropods and the lack of diatom extinction events during the Late Pleistocene/Holocene remain largely unknown. However, the lack of environmentally induced extinction events in Lake Ohrid and/or the high resilience of its ecosystems may have played a role (Föller et al., 2015; Cvetkoska et al., 2016; Jovanovska et al., 2016). Local buffering from extreme environmental effects in a refugial area, such as Lake Ohrid, may have not only led to reduced extinction rates but also allowed divergence of lineages to proceed. Refugia thus may have acted both as "museums" for the conservation of diversity and as "cradles" for the production of new diversity (Tzedakis et al., 2002; Tzedakis, 2009). Nonetheless, though environmental changes may have had only a minor direct effect on diversification processes in endemic taxa of Lake Ohrid during the last $637 \mathrm{kyr}$, these changes potentially altered the abundance and community compositions of diatoms and ostracods (e.g. Belmecheri et al., 2010; Reed et al., 2010; Zhang et al., 2016), thus indirectly affecting speciation processes. In fact, the analysis of the gastropod community in Lake Ohrid implied the presence of both geographical and ecological speciation due to physical barriers and divergence across environmental or life history gradients, respectively (Hauffe et al., 2016).

Another aspect of environmental change is the impact of anthropogenic activity on species composition, diversity, and diversification. As previously suggested, Lake Ohrid is facing a "creeping biodiversity crisis", as increasing human impact in and around the lake already jeopardises endemic species (Kostoski et al., 2010). For example, the presence of globally invasive species has been recently demonstrated for Lake Ohrid (Albrecht et al., 2014). Moreover, humanmediated environmental change is also predicted to alter the trophic state of the lake (e.g. Matzinger et al., 2006). Given the small size of both the lake and its catchment, increasing negative effects on the endemic biodiversity of Lake Ohrid and the respective habitats are foreseeable and will likely foster extirpation. Only concerted and international conservation activities might help mitigating the human impact on the sensitive and highly biodiverse ecosystem of Lake Ohrid. 


\section{Conclusions and outlook}

The SCOPSCO deep drilling project was initiated in 2004 and aimed at inferring (i) the age and origin of Lake Ohrid (Former Yugoslav Republic of Macedonia/Republic of A1bania), (ii) its regional seismotectonic history, (iii) volcanic activity and climate change in the central northern Mediterranean region, and (iv) the influence of major geological events on the evolution of its endemic species. The project included phylogenetic and metacommunity analyses of living invertebrates and sampling from main modern terrestrial organic matter pools from the lake and its surroundings, seismic and hydro-acoustic surveys of the lake's internal sediment architecture, and the recovery of surface sediments and sediment cores. Within the framework of the ICDP a deep drilling in Lake Ohrid took place in spring 2013 and provided, among others, a $584 \mathrm{~m}$ long sediment sequence from the central part (DEEP site) of the lake. Initial results of the study of this sediment sequence in combination with the results of the biological and geophysical as well as former sedimentological studies reveal that the Ohrid basin formed during the Miocene and Pliocene. Lake Ohrid established between 1.9 and 1.3 Ma and provides a continuous record of distal tephra deposition and climatic and environmental change in the central northern Mediterranean region. With its geographical location, the Lake Ohrid record provides a unique opportunity to align marine records from the North Atlantic with long-term and independently dated terrestrial archives in the northern and eastern Mediterranean, such as the records from the Sulmona basin, Tenaghi Philippon, Lake Van, or Dead Sea. This is a major precondition to disentangle longitudinal climate gradients and investigate leads and lags circumventing age model uncertainties.

More detailed studies exist meanwhile on the upper $247.8 \mathrm{~m}$ of the DEEP site sediment sequence and indicate that this part represents the last 637 kyr. Over this period, Lake Ohrid experienced significant environmental change, which is related to orbital-scale climate forcing and regional geological events. These changes apparently did not cause major extinction events in Lake Ohrid, as evident from both the microgastropod phylogeny and the diatom fossil record. The potential high resilience of the ecosystem to past climatic and environmental changes together with relatively low extinction rates may explain the extraordinary degree of endemic biodiversity in the lake. Ongoing biological studies and more detailed analyses of the early stages of Lake Ohrid basin, based on the now accessible sediment records, will help to better understand the drivers of biological diversification and endemism. Lake Ohrid is thus a key site to further resolve the link between biological and geological evolution and should centre our attention on protecting the endemic community from a substantial biodiversity crisis due to the increasing anthropogenic impact.
Data availability. Data are stored at the Drilling Information System (DIS) of ICDP (www.icdp-online.org) and at the Pangaea database (www.pangaea.de).

Competing interests. The authors declare that they have no conflict of interest.

Acknowledgements. The SCOPSCO Lake Ohrid drilling project was funded by ICDP, the German Ministry of Higher Education and Research, the German Research Foundation, the University of Cologne, the British Geological Survey, the INGV and CNR (both Italy), and the governments of the republics of Macedonia (FYROM) and Albania. The Hydrobiological Institute in Ohrid (S. Trajanovski and G. Kostoski) and the Hydrometeorological Institute in Tirana (M. Sanxhaku and B. Lushaj) provided logistic support for pre-site surveys and the deep drilling campaign. Drilling was carried out by Drilling, Observation and Sampling of the Earth's Continental Crust (DOSECC) and using the Deep Lake Drilling System (DLDS). We also would like to thank P. Tzedakis and an anonymous reviewer for the positive feedback and valuable suggestions to improve the manuscript.

Edited by: J. Kesselmeier

Reviewed by: P. C. Tzedakis and one anonymous referee

\section{References}

Albrecht, C. and Wilke, T.: Ancient Lake Ohrid: biodiversity and evolution, Hydrobiologia, 615, 103-140, doi:10.1007/9781-4020-9582-5_9, 2008.

Albrecht, C., Trajanovski, S., Kuhn, K., Streit, B., and Wilke, T.: Rapid evolution of an ancient lake species flock: freshwater limpets (Gastropoda: Ancylidae) in the Balkan lake Ohrid, Organisms, Diversity and Evolution, 6, 294-307, doi:10.1016/j.ode.2005.12.003, 2006.

Albrecht, C., Wolf, C., Glöer, P., and Wilke, T.: Concurrent evolution of ancient sister lakes and sister species: The freshwater gastropod genus Radix in lakes Ohrid and Prespa, Hydrobiologia, 615, 157-167, doi:10.1007/s10750-008-9555-1, 2008.

Albrecht, C., Vogel, H., Hauffe, T., and Wilke, T.: Sediment core fossils in ancient Lake Ohrid: testing for faunal change since the Last Interglacial, Biogeosciences, 7, 3435-3446, doi:10.5194/bg-7-3435-2010, 2010.

Albrecht, C., Föller, K., Hauffe, T., Clewing, C., and Wilke, T.: Invaders versus endemics: alien gastropod species in ancient Lake Ohrid, Hydrobiologia, 739, 163-174, doi:10.1007/s10750-0131724-1, 2014.

Aliaj, S., Baldassarre, G., and Shkupi, D.: Quaternary subsidence zones in Albania: some case studies, B. Eng. Geol. Environ., 59, 313-318, doi:10.1007/s100640000063, 2001.

Ambrosetti, W., Barbanti, L., and Sala, N.: Residence time and physical processes in lakes, J. Limnol., 62, 1-15, doi:10.4081/jlimnol.2003.s1.1, 2003.

Barker, S., Knorr, G., Edwards, R. L., Parrenin, F., Putnam, A. E., Skinner, L. C., Wolff, E., and Ziegler, M.: 800,000 
years of abrupt climate variability, Science, 334, 347-351, doi:10.1126/science.1203580, 2011.

Baumgarten, H., Wonik, T., Tanner, D. C., Francke, A., Wagner, B., Zanchetta, G., Sulpizio, R., Giaccio, B., and Nomade, S.: Age-depth model of the past $630 \mathrm{kyr}$ for Lake Ohrid (FYROM/Albania) based on cyclostratigraphic analysis of downhole gamma ray data, Biogeosciences, 12, 7453-7465, doi:10.5194/bg-12-7453-2015, 2015.

Belmecheri, S., Namiotko, T., Robert, C., von Grafenstein, U., and Danielopol, D. L.: Climate controlled ostracod preservation in Lake Ohrid (Albania, Macedonia), Palaeogeogr. Palaeocl., 277, 236-245, doi:10.1016/j.palaeo.2009.04.013, 2009.

Belmecheri, S., von Grafenstein, U., Andersen, N., EymardBordon, A., Régnier, D., Grenier, C., and Lézine, A.-M.: Ostracod-based isotope record from Lake Ohrid (Balkan Peninsula) over the last $140 \mathrm{ka}$, Quaternary Sci. Rev., 29, 3894-3904, doi:10.1016/j.quascirev.2010.09.011, 2010.

Bond, G., Heinrich, H., Huon, S., Broecker, W., Labeyrie, L., Andrews, J., McManus, J., Clasen, S., Tedesco, K., Jantschik, R., Simet, C., and Klas, M.: Evidence for massive discharges of icebergs into the Northern Atlantic, Nature, 360, 245-249, 1992.

Bond, G., Broecker, W., Johnsen, S., McManus, J., Labeyrie, L., Jouzel, J., and Bonani, G.: Correlations between climate records from North Atlantic sediments and Greenland ice, Nature, 365, 143-147, 1993.

Capotondi, L., Girone, A., Lirer, F., Bergami, C., Verducci, M., Vallefuoco, M., Afferri, A., Ferraro, L., Pelosi, N., and De Lange, G. J.: Central Mediterranean Mid-Pleistocene paleoclimatic variability and its association with global climate, Palaeogeogr. Palaeocl., 442, 72-83, doi:10.1016/j.palaeo.2015.11.009, 2016.

Clark, P. U., Archer, D., Pollard, D., Blum, J. D., Rial, J. A., Brovkin, V., Mix, A. C., Pisias, N. G., and Roy, M.: The middle Pleistocene transition: characteristics, mechanisms, and implications for long-term changes in atmospheric $p \mathrm{CO}_{2}$, Quaternary Sci. Rev., 25, 3150-3184, doi:10.1016/j.quascirev.2006.07.008, 2006.

Cvetkoska, A., Levkov, Z., Reed, J. M., Wagner, B., Panagiotopoulos, K., Leng, M. J., and Lacey, J.: Quaternary climate change and Heinrich events in the southern Balkans: Lake Prespa diatom palaeolimnology from the last interglacial to present, J. Paleolimnol., 53, 215-231, doi:10.1007/s10933-014-9821-3, 2015.

Cvetkoska, A., Jovanovska, E., Francke, A., Tofilovska, S., Vogel, H., Levkov, Z., Donders, T. H., Wagner, B., and Wagner-Cremer, F.: Ecosystem regimes and responses in a coupled ancient lake system from MIS $5 \mathrm{~b}$ to present: the diatom record of lakes Ohrid and Prespa, Biogeosciences, 13, 3147-3162, doi:10.5194/bg-133147-2016, 2016.

Cvijić, J.: L'ancient Lac Égéen, Ann. Geogr., 20, 233-259, 1911.

D’Addabbo, M., Sulpizio, R., Guidi, M., Capitani, G., Mantecca, P., and Zanchetta, G.: Ash leachates from some recent eruptions of Mount Etna (Italy) and Popocatépetl (Mexico) volcanoes and their impact on amphibian living freshwater organisms, Biogeosciences, 12, 7087-7106, doi:10.5194/bg-12-7087-2015, 2015.

Dansgaard, W., Johnsen, S. J., Clausen, H. B., Hvidberg, C. S., and Steffensen, J. P.: Evidence for general instability of past climate from a 250-kyr, Nature, 364, 218-220, doi:10.1038/364218a0, 1993.
Damaschke, M., Sulpizio, R., Zanchetta, G., Wagner, B., Böhm, A., Nowaczyk, N., Rethemeyer, J., and Hilgers, A.: Tephrostratigraphic studies on a sediment core from Lake Prespa in the Balkans, Clim. Past, 9, 267-287, doi:10.5194/cp-9-267-2013, 2013.

Dumurdzanov, N., Serafimovski, T., and Burchfiel, B. C.: Evolution of the Neogene-Pleistocene basins of Macedonia, Geological Society of America Digital Map and Chart Series 1, Skopje, 2004.

Em, H., Dzhekov, S., and Rizovski, R.: Refugial forest vegetation in SR Macedonia, Contributions, 6, 5-20, 1985.

Filipovski, G., Rizovski, R., and Ristevski, P.: The characteristics of the climate-vegetation-soil zones (regions) in the Republic of Macedonia, Macedonian Academy of Sciences and Arts, Skopje, 178 pp., 1996.

Fletcher, W. J., Müller, U. C., Koutsodendris, A., Christanis, K., and Pross, J.: A centennial-scale record of vegetation and climate variability from 312 to $240 \mathrm{ka}$ (Marine Isotope Stages 9c-a, 8 and 7e) from Tenaghi Philippon, NE Greece, Quaternary Sci. Rev., 78, 108-125, doi:10.1016/j.quascirev.2013.08.005, 2013.

Forel, F. A.: Handbuch der Seenkunde, 249 pp., Stuttgart, Verlag J. Engelhorn, 1901.

Föller, K., Stelbrink, B., Hauffe, T., Albrecht, C., and Wilke, T.: Constant diversification rates of endemic gastropods in ancient Lake Ohrid: ecosystem resilience likely buffers environmental fluctuations, Biogeosciences, 12, 7209-7222, doi:10.5194/bg12-7209-2015, 2015.

Francke, A., Wagner, B., Just, J., Leicher, N., Gromig, R., Baumgarten, H., Vogel, H., Lacey, J. H., Sadori, L., Wonik, T., Leng, M. J., Zanchetta, G., Sulpizio, R., and Giaccio, B.: Sedimentological processes and environmental variability at Lake Ohrid (Macedonia, Albania) between $637 \mathrm{ka}$ and the present, Biogeosciences, 13, 1179-1196, doi:10.5194/bg-13-1179-2016, 2016.

Genty, D., Blamart, D., Ouahdi, R., Gilmour, M., Baker, A., Jouzel, J., and Van-Exter, S.: Precise dating of Dansgaard-Oeschger climate oscillations in western Europe from stalagmite data, Nature, 421, 833-837, doi:10.1038/nature01391, 2003.

Giaccio, B., Niespolo, E., Pereira, A., Nomade, S., Renne , P. R., Albert, P. G., Arienzo, I., Regattieri, E., Wagner, B., Zanchetta, G., Gaeta, M., Galli, P., Mannella, G., Peronace, E., Sottili, G., Florindo, F., Leicher, N., Marra, F., and Tomlinson, E. L.: First integrated tephrochronological record for the last $\sim 190 \mathrm{kyr}$ from the Fucino Quaternary lacustrine succession, central Italy, Quaternary Sci. Rev., 158, 211-234, doi:10.1016/j.quascirev.2017.01.004, 2017.

Girone, A., Maiorano, P., Marino, M., and Kucera, M.: Calcareous plankton response to orbital and millennial-scale climate changes across the Middle Pleistocene in the western Mediterranean, Palaeogeogr. Palaeocl., 392, 105-116, doi:10.1016/j.palaeo.2013.09.005, 2013.

Grandcolas, P., Nattier, R., and Trewick, S.: Relict species: a relict concept?, Trends Ecol. Evol., 29, 655-663, doi:10.1016/j.tree.2014.10.002, 2014.

Hauffe, T., Albrecht, C., and Wilke, T.: Assembly processes of gastropod community change with horizontal and vertical zonation in ancient Lake Ohrid: a metacommunity speciation perspective, Biogeosciences, 13, 2901-2911, doi:10.5194/bg-13-2901-2016, 2016.

Hauswald, A. K., Albrecht, C., and Wilke, T.: Testing two contrasting evolutionary patterns in ancient lakes: species flock versus 
species scatter in valvatid gastropods of Lake Ohrid, Hydrobiologia, 615, 169-179, doi:10.1007/978-1-4020-9582-5_12, 2008.

Hemming, S. R.: Heinrich events: Massive late Pleistocene detritus layers of the North Atlantic and their global climate imprint, Rev. Geophys., 42, RG1005, doi:10.1029/2003RG000128, 2004.

Hodell, D. A., Channell, J. E. T., Curtis, J. H., Romero, O. E., and Röhl, U.: Onset of "Hudson Strait" Heinrich events in the eastern North Atlantic at the end of the middle Pleistocene transition $(\sim 640 \mathrm{ka})$ ?, Paleoceanography, 23, PA4218, doi:10.1029/2008PA001591, 2008.

Holtvoeth, J., Vogel, H., Wagner, B., and Wolff, G. A.: Lipid biomarkers in Holocene and glacial sediments from ancient Lake Ohrid (Macedonia, Albania), Biogeosciences, 7, 3473-3489, doi:10.5194/bg-7-3473-2010, 2010.

Holtvoeth, J., Rushworth, D., Copsey, H., Imeri, A., Cara, M., Vogel, H., Wagner, T., and Wolff, G. A.: Improved endmember characterisation of modern organic matter pools in the Ohrid Basin (Albania, Macedonia) and evaluation of new palaeoenvironmental proxies, Biogeosciences, 13, 795-816, doi:10.5194/bg-13-795-2016, 2016.

Hughes, P. D., Gibbard, P. L., and Woodward, J. C.: Middle Pleistocene glacier behaviour in the Mediterranean: sedimentological evidence from the Pindus Mountains, Greece, J. Geol. Soc., 163, 857-867, doi:10.1144/0016-76492005-131, 2006.

Imeri, A., Mullaj, A., Gjeta, E., Kalajnxhiu, A., Kupe, L., Shehu, J., and Dodona, E.: Preliminary results from the study of flora and vegetation of Ohrid lake, Natura Montenegrina, 9, 253-264, 2010.

Jordanoski, M., Naumoski, T., and Veljanoska-Sarafiloska E.: Physical and chemical investigations of Ohrid and Prespa lake and their tributaries, in: Lakes Ohrid and Prespa monitoring program, 3rd report, edited by: Mitic, V., Hydrobiological Institute Ohrid, 9-20, 2004.

Jordanoski, M., Naumoski, T., and Veljanoska-Sarafiloska E.: Physical and chemical investigations of Ohrid and Prespa lake and their tributaries for the period of 2003 year, in: Limnological investigations of Ohrid and Prespa lakes, $3 \& 4$, edited by: Mitic, V., Hydrobiological Institute Ohrid, 9-25, 2005.

Jovanovska, E., Cvetkoska, A., Hauffe, T., Levkov, Z., Wagner, B., Sulpizio, R., Francke, A., Albrecht, C., and Wilke, T.: Differential resilience of ancient sister lakes Ohrid and Prespa to environmental disturbances during the Late Pleistocene, Biogeosciences, 13, 1149-1161, doi:10.5194/bg-13-1149-2016, 2016.

Just, J., Nowaczyk, N. R., Sagnotti, L., Francke, A., Vogel, H., Lacey, J. H., and Wagner, B.: Environmental control on the occurrence of high-coercivity magnetic minerals and formation of iron sulfides in a $640 \mathrm{ka}$ sediment sequence from Lake Ohrid (Balkans), Biogeosciences, 13, 2093-2109, doi:10.5194/bg-132093-2016, 2016.

Kostoski, G., Albrecht, C., Trajanovski, S., and Wilke, T.: A freshwater biodiversity hotspot under pressure - assessing threats and identifying conservation needs for ancient Lake Ohrid, Biogeosciences, 7, 3999-4015, doi:10.5194/bg-7-3999-2010, 2010.

Lacey, J., Francke, A., Leng, M. J., Vane, C. H., and Wagner, B.: A high resolution Late Glacial to Holocene record of environmental change in the Mediterranean from Lake Ohrid (Macedonia/Albania), Int. J. Earth Sci., 104, 1623-1638, doi:10.1007/s00531-014-1033-6, 2015.
Lacey, J. H., Leng, M. J., Francke, A., Sloane, H. J., Milodowski, A., Vogel, H., Baumgarten, H., Zanchetta, G., and Wagner, B.: Northern Mediterranean climate since the Middle Pleistocene: a $637 \mathrm{ka}$ stable isotope record from Lake Ohrid (Albania/Macedonia), Biogeosciences, 13, 1801-1820, doi:10.5194/bg-13-1801-2016, 2016.

Leicher, N., Zanchetta, G., Sulpizio, R., Giaccio, B., Wagner, B., Nomade, S., Francke, A., and Del Carlo, P.: First tephrostratigraphic results of the DEEP site record from Lake Ohrid (Macedonia and Albania), Biogeosciences, 13, 2151-2178, doi:10.5194/bg-13-2151-2016, 2016.

Leng, M. J., Baneschi, I., Zanchetta, G., Jex, C. N., Wagner, B., and Vogel, H.: Late Quaternary palaeoenvironmental reconstruction from Lakes Ohrid and Prespa (Macedonia/Albania border) using stable isotopes, Biogeosciences, 7, 3109-3122, doi:10.5194/bg7-3109-2010, 2010.

Leng, M. J., Wagner, B., Aufgebauer, A., Panagiotopoulos, K., Vane, C., Snelling, A., Haidon, C., Woodley, E., Vogel, H., Zanchetta, G., Sulpizio, R., and Baneschi, I.: Understanding past climatic and hydrological variability in the Mediterranean from Lake Prespa sediment isotope and geochemical record over the last glacial cycle, Quaternary Sci. Rev., 66, 123-136, doi:10.1016/j.quascirev.2012.07.015, 2013.

Lindhorst, K., Vogel, H., Krastel, S., Wagner, B., Hilgers, A., Zander, A., Schwenk, T., Wessels, M., and Daut, G.: Stratigraphic analysis of lake level fluctuations in Lake Ohrid: an integration of high resolution hydro-acoustic data and sediment cores, Biogeosciences, 7, 3531-3548, doi:10.5194/bg-7-3531-2010, 2010.

Lindhorst, K., Gruen, M., Krastel, S., and Schwenk, T.: Hydroacoustic Analysis of Mass Wasting Deposits in Lake Ohrid (FYR Macedonia/Albania), in: Submarine Mass Movements and Their Consequences, edited by: Yamada, Y., Kawamura, K., Ikehara, K., Ogawa, Y., Urgeles, R., Mosher, D., Chaytor, J., and Strasser, M., Springer, the Netherlands, 245-253, 2012.

Lindhorst, K., Krastel, S., Reicherter, K., Stipp, M., Wagner, B., and Schwenk, T.: Sedimentary and tectonic evolution of Lake Ohrid (Macedonia/Albania), Basin Res., 27, 84-101, doi:10.1111/bre.12063, 2015.

Lindhorst, K., Krastel, S., and Baumgarten, H.: Mass Wasting history within Lake Ohrid Basin (Macedonia/Albania) over the last $600 \mathrm{ka}$, Submarine Mass Movements and their Consequences: 7th International Symposium, edited by: Lamarche, G., Mountjoy, J., Bull, S., Hubble, T., Krastel, S., Lane, E., Micallef, A., Moscardelli, L., Mueller, C., Pecher, I., and Woelz, S., Springer International Publishing, 291-300, 2016.

Lisiecki, L. E. and Raymo, M. E.: A Pliocene-Pleistocene stack of 57 globally distributed benthic $\partial^{18} \mathrm{O}$ records, Paleoceanography, 20, PA1003, doi:10.1029/2004PA001071, 2005.

Margari, V., Gibbard, P. L., Bryant, C. L., and Tzedakis, P. C.: Character of vegetational and environmental changes in southern Europe during the last glacial period; evidence from Lesvos Island, Greece, Quaternary Sci. Rev., 28, 1317-1339, doi:10.1016/j.quascirev.2009.01.008, 2009.

Margari, V., Skinner, L. C., Tzedakis, P. C., Ganopolski, A., Vautravers, M., and Shackleton, N. J.: The nature of millennialscale climate variability during the past two glacial periods, Nat. Geosci., 3, 127-131, doi:10.1038/ngeo740, 2010.

Matevski, V., Carni, A., Avramovski, O., Juvan, N., Kostadinovski, M., Košir, P., Marinšek, A., Paušic, A., and Šilc, U.: Forest Veg- 
etation of the Galicica Mountain Range in Macedonia, Založba ZRC, Ljubljana, 2011.

Martrat, B., Grimalt, J. O., Lopez-Martinez, C., Cacho, I., Sierro, F. J., Flores, J. A., Zahn, R., Canals, M., Curtis, J. H., and Hodell, D. A.: Abrupt temperature changes in the Western Mediterranean over the past 250,000 years, Science, 306, 1762-1765, doi:10.1126/science.1101706, 2004.

Matter, M., Anselmetti, F. S., Jordanoska, B., Wagner, B., Wessels, M., and Wüest, A.: Carbonate sedimentation and effects of eutrophication observed at the Kališta subaquatic springs in Lake Ohrid (Macedonia), Biogeosciences, 7, 3755-3767, doi:10.5194/bg-7-3755-2010, 2010.

Matzinger, A., Spirkovski, Z., Patceva, S., and Wüest, A.: Sensitivity of ancient Lake Ohrid to local anthropogenic impacts and global warming, J. Great Lakes Res., 32, 158-179, doi:10.3394/0380-1330(2006)32[158:SOALOT]2.0.CO;2, 2006.

Matzinger, A., Schmid, M., Veljanoska-Sarafiloska, E., Patceva, S., Guseska, D., Wagner, B., Müller, B., Sturm, M., and Wüest, A.: Eutrophication of ancient Lake Ohrid: Global warming amplifies detrimental effects of increased nutrient inputs, Limnol. Oceanogr., 52, 338-353, doi:10.4319/lo.2007.52.1.0338, 2007.

Melles, M., Brigham-Grette, J., Minyuk, P. S., Nowaczyk, N. R., Wennrich, V., DeConto, R. .M, Anderson, P. M., Andreev, A. A., Coletti, A., Cook, T. L., Haltia-Hovi, E., Kukkonen, M., Lozhkin, A. V., Rosén, P., Tarasov, P., Vogel, H., and Wagner, B.: 2.8 Million years of Arctic Climate Change from Lake El'gygytgyn, NE Russia, Science 337, 315-320, doi:10.1126/science.1222135, 2012.

McManus, J. F., Oppo, D. W., and Cullen, J. L.: A 0.5million-year record of millennial-scale climate variability in the North Atlantic, Science, 283, 971-975, doi:10.1126/science.283.5404.971, 1999.

Müller, U. C., Pross, J., Tzedakis, P. C., Gamble, C., Kotthoff, U., Schmiedl, G., Wulf, S., and Christanis, K.: The role of climate in the spread of modern humans into Europe, Quaternary Sci. Rev., 30, 273-279, doi:10.1016/j.quascirev.2010.11.016, 2011.

Naafs, B. D. A., Hefter, J., Ferretti, P., Stein, R., and Haug, G. H.: Sea surface temperatures did not control the first occurrence of Hudson Strait Heinrich Events during MIS 16, Paleoceanography, 26, PA4201, doi:10.1029/2011PA002135, 2011.

Naafs, B. D. A., Hefter, J., and Stein, R.: Millennial-scale ice rafting events and Hudson Strait Heinrich(-like) events during the late Pliocene and Pleistocene: A review, Quaternary Sci. Rev., 80, 128, doi:10.1016/j.quascirev.2013.08.014, 2013.

Naafs, B. D. A., Hefter, J., and Stein, R.: Dansgaard-Oeschger forcing of sea surface temperature variability in the midlatitude North Atlantic between 500 and $400 \mathrm{ka}$ (MIS 12), Paleoceanography, 29, 1024-1030, doi:10.1002/2014PA002697, 2014.

National Research Council: Freshwater ecosystems: Re-vitalizing educational programs in limnology, National Academy Press, Washington, DC, 364 pp., 1996.

Naumoski, T., Jordanoski, M., and Veljanoska-Sarafiloska E.: Physical and chemical characteristics of Lake Ohrid, in: Limnological investigations of Ohrid and Prespa lakes, 5, edited by: Guseka, D., Hydrobiological Institute Ohrid, 8-23, 2007.

Nowaczyk, N. R., Haltia, E. M., Ulbricht, D., Wennrich, V., Sauerbrey, M. A., Rosén, P., Vogel, H., Francke, A., MeyerJacob, C., Andreev, A. A., and Lozhkin, A. V.: Chronology of Lake El'gygytgyn sediments - a combined magnetostrati- graphic, palaeoclimatic and orbital tuning study based on multiparameter analyses, Clim. Past, 9, 2413-2432, doi:10.5194/cp-92413-2013, 2013.

Panagiotopoulos, K., Böhm, A., Leng, M. J., Wagner, B., and Schäbitz, F.: Climate variability over the last $92 \mathrm{ka}$ in SW Balkans from analysis of sediments from Lake Prespa, Clim. Past, 10, 643-660, doi:10.5194/cp-10-643-2014, 2014.

Popovska, C. and Bonacci, O.: Basic data on the hydrology of Lakes Ohrid and Prespa, Hydrol. Process., 21, 658-664, 2007.

Raymo, M. E., Ganley, K., Carter, S., Oppo, D. W., and McManus, J.: Millennial-scale climate instability during the early Pleistocene epoch, Nature, 392, 699-702, doi:10.1038/33658, 1998.

Reed, J. M., Cvetkoska, A., Levkov, Z., Vogel, H., and Wagner, B.: The last glacial-interglacial cycle in Lake Ohrid (Macedonia/Albania): testing diatom response to climate, Biogeosciences, 7, 3083-3094, doi:10.5194/bg-7-3083-2010, 2010.

Regattieri, E., Giaccio, B., Zanchetta, G., Drysdale, R. N., Galli, P., Nomade, S., Peronace, E., and Wulf, S.: Hydrological variability over Apennine during the Early Last Glacial precession minimum, as revealed by a stable isotope record from Sulmona basin, central Italy, J. Quaternary Sci., 30, 19-31, doi:10.1002/jqs.2755, 2015.

Regattieri, E., Giaccio, B., Galli, P., Nomade, S., Peronace, E.,Messina P., Sposato, A., Boschi, C., and Gemelli, M.: A multiproxy record of MIS 11-12 deglaciation and glacial MIS 12 instability from the Sulmona Basin (central Italy), Quaternary Sci. Rev., 132, 129-145, doi:10.1016/j.quascirev.2015.11.015, 2016.

Reicherter, K., Hoffmann, N., Lindhorst, K., Krastel, S., FernandezSteeger, T., Grützner, C., and Wiatr, T.: Active Basins and Neotectonics: Morphotectonics of the Lake Ohrid Basin (FYROM and Albania), Z. Dtsch. Ges. Geowiss., 162, 217-234, 2011.

Rohling, E. J., Mayewski, P. A., and Challenor, P.: On the timing and mechanism of millennial-scale climate variability during the last glacial cycle, Clim. Dynam., 20, 257-267, doi:10.1007/s00382-002-0266-4, 2003.

Rohling, E. J., Foster, G. L., Grant, K. M., Marino, G., Roberts, A. P., Tamisiea, M. E., and Williams, F.: Sea-level and deep-seatemperature variability over the past 5.3 million years, Nature, 508, 477-482, doi:10.1038/nature13230, 2014.

Roucoux, K. H., Shackleton, N. J., de Abreu, L., Schönfeld, J., and Tzedakis, P. C.: Combined marine proxy and pollen analyses reveal rapid Iberian vegetation response to North Atlantic millennial-scale climate oscillations, Quaternary Res., 56, 128132, doi:10.1006/qres.2001.2218, 2001.

Roucoux, K. H., Tzedakis, P. C., Lawson, I. T., and Margari, V.: Vegetation history of the penultimate glacial period (Marine isotope stage 6) at Ioannina, north-west Greece, J. Quaternary Sci., 26, 616-626, doi:10.1002/jqs.1483, 2011.

Sadori, L., Koutsodendris, A., Panagiotopoulos, K., Masi, A., Bertini, A., Combourieu-Nebout, N., Francke, A., Kouli, K., Joannin, S., Mercuri, A. M., Peyron, O., Torri, P., Wagner, B., Zanchetta, G., Sinopoli, G., and Donders, T. H.: Pollen-based paleoenvironmental and paleoclimatic change at Lake Ohrid (south-eastern Europe) during the past $500 \mathrm{ka}$, Biogeosciences, 13, 1423-1437, doi:10.5194/bg-13-1423-2016, 2016.

Sanchez-Goñi, M., Cacho, I., Turon, J. L., Guiot, J., Sierro, F., Peypouquet, J., Grimalt, J., and Shackleton, N.: Synchroneity between marine and terrestrial responses to millennial scale climatic variability during the last glacial period in the Mediter- 
ranean region, Clim. Dynam., 19, 95-105, doi:10.1007/s00382001-0212-x, 2002.

Schneider, S., Cara, M., Eriksen, T. E., Budzakoska Goreska, B., Imeri, A., Kupe, L., Loshkoska, T., Patceva, S., Trajanovska, S., Trajanovski, S., Talevska, M., and Veljanovska Sarafilovska, E.: Eutrophication impacts littoral biota in Lake Ohrid while water phosphorus concentrations are low, Limnologica, 44, 90-97, doi:10.1016/j.limno.2013.09.002, 2014.

Schreiber, K., Hauffe, T., Albrecht, C., and Wilke, T.: The role of barriers and gradients in differentiation processes of pyrgulinid microgastropods of Lake Ohrid, Hydrobiologia, 682, 6173, doi:10.1007/s10750-011-0864-4, 2012.

Schultheiß, R., Albrecht, C., Bößneck, U., and Wilke, T.: The neglected side of speciation in ancient lakes: phylogeography of an inconspicuous mollusc taxon in lakes Ohrid and Prespa, Hydrobiologia, 615, 141-156, doi:10.1007/978-1-4020-9582-5_10, 2008.

Seierstad, I. K., Abbott, P. M., Bigler, M., Blunier, T., Bourne, A.J., Brook, E., Buchardt, S. L., Buizert, C., Clausen, H. B., Cook, E., Dahl-Jensen, D., Davies, S. M., Guillevic, M., Johnsen, S. J., Pedersen, D. S., Popp, T. J., Rasmussen, S. O., Severinghaus, J. P., Svensson, A., and Vinther, B. M.: Consistently dated records from the Greenland GRIP, GISP2 and NGRIP ice cores for the past $104 \mathrm{ka}$ reveal regional millennial-scale $\delta^{18} \mathrm{O}$ gradients with possible Heinrich event imprint, Quaternary Sci. Rev., 106, 29—46, doi:10.1016/j.quascirev.2014.10.032, 2014.

Shackleton, N. J.: Oxygen isotopes, ice volume and sea level, Quaternary Sci. Rev., 6, 183-190, doi:10.1016/0277-3791(87)900035, 1987.

Shackleton, N. J., Hall, M. A., and Vincent, E.: Phase relationships between millennial-scale events 64,000-24,000 years ago, Paleoceanography, 15, 565-569, doi:10.1029/2000PA000513, 2000.

Stanković, S.: The Balkan Lake Ohrid and its living world, Dr. W. Junk, The Hague, 1960.

Stein, R., Hefter, J., Grützner, J., Voelker, A., and Naafs, B. D. A.: Variability of surface-water characteristics and Heinrich-like events in the Pleistocene mid-latitude North Atlantic Ocean: Biomarker and XRD records from IODP Site U1313 (MIS 169), Paleoceanography, 24, PA2203, doi:10.1029/2008PA001639, 2009.

Stockhecke, M., Kwiecien, O., Vigliotti, L., Anselmetti, F. S., Beer, J., Çagatay, M. N., Channell, J. E. T., Kipfer, R., Lachner, J., Litt, T., Pickarski, N., and Sturm, M.: Chronostratigraphy of the 600,000 year old continental record of Lake Van (Turkey), Quaternary Sci. Rev., 104, 8-17, doi:10.1016/j.quascirev.2014.04.008, 2014.

Stockhecke, M., Timmermann, A., Kipfer, R., Haug, G. H., Kwiecien, O., Friedrich, T., Menviel, L., Litt, T., Pickarski, N., and Anselmetti, F. S.: Millennial to orbital-scale variations of drought intensity in the Eastern Mediterranean, Quaternary Sci. Rev., 133, 77-95, doi:10.1016/j.quascirev.2015.12.016, 2016.

Sulpizio, R., Zanchetta, G., D’Orazio, M., Vogel, H., and Wagner, B.: Tephrostratigraphy and tephrochronology of lakes Ohrid and Prespa, Balkans, Biogeosciences, 7, 3273-3288, doi:10.5194/bg7-3273-2010, 2010.

Sušnik, S., Knizhin, I., Snoj, A., and Weiss, S.: Genetic and morphological characterization of a Lake Ohrid endemic, Salmo (Acantholingua) ohridanus with a comparison to sympatric
Salmo trutta, J. Fish. Biol., 68, 2-23, doi:10.1111/j.00221112.2006.00902.x, 2006.

Thienemann, A.: Untersuchungen über die Beziehung zwischen dem Sauerstoffgehalt des Wassers und der Zusammensetzung der Fauna in norddeutschen Seen, A. Hydrobiol., 12, 1-65, 1918.

Trajanovski, S., Albrecht, C., Schreiber, K., Schultheiß, R., Stadler, T., Benke, M., and Wilke, T.: Testing the spatial and temporal framework of speciation in an ancient lake species flock: the leech genus Dina (Hirudinea: Erpobdellidae) in Lake Ohrid, Biogeosciences, 7, 3387-3402, doi:10.5194/bg-7-3387-2010, 2010.

Tzedakis, P.: Vegetation change through glacial-interglacial cycles: a long pollen sequence perspective, Philos. T. R. Soc. B, 345, 403-432, doi:10.1098/rstb.1994.0118, 1994.

Tzedakis, P. C.: Museums and cradles of Mediterranean biodiversity, J. Biogeogr., 36, 1033-1034, doi:10.1111/j.13652699.2009.02123.x, 2009.

Tzedakis, P. C., Lawson, I. T., Frogley, M. R., Hewitt, G. M., and Preece, R. C.: Buffered tree population changes in a Quaternary refugium: evolutionary implications, Science, 297, 2044-2047, doi:10.1126/science.1073083, 2002.

Tzedakis, P. C., Frogley, M. R., Lawson, I. T., Preece, R. C., Cacho, I., and De Abreu, L.: Ecological thresholds and patterns of millennial-scale climate variability: the response of vegetation in Greece during the last glacial period, Geology, 32, 109-112, doi:10.1130/G20118.1, 2004.

Tzedakis, P. C., Hooghiemstra, H., and Pälike, H.: The last 1.35 million years at Tenaghi Philippon: revised chronostratigraphy and long-term vegetation trends, Quaternary Sci. Rev., 25, 34163430, doi:10.1016/j.quascirev.2006.09.002, 2006.

Voelker, A. H. L., Rodrigues, T., Billups, K., Oppo, D., McManus, J., Stein, R., Hefter, J., and Grimalt, J. O.: Variations in midlatitude North Atlantic surface water properties during the midBrunhes (MIS 9-14) and their implications for the thermohaline circulation, Clim. Past, 6, 531-552, doi:10.5194/cp-6-531-2010, 2010.

Vogel, H., Wagner, B., Zanchetta, G., Sulpizio, R., and Rosén, P.: A paleoclimate record with tephrochronological age control for the last glacial-interglacial cycle from Lake Ohrid, Albania and Macedonia, J. Paleolimnol., 44, 295-310, doi:10.1007/s10933009-9404-x,2010a.

Vogel, H., Zanchetta, G., Sulpizio, R., Wagner, B., and Nowaczyk, N.: A tephrostratigraphic record for the last glacial-interglacial cycle from Lake Ohrid, Albania and Macedonia, J. Quaternary Sci., 25, 320-338, doi:10.1002/jqs.1311, 2010b.

Vogel, H., Wessels, M., Albrecht, C., Stich, H.-B., and Wagner, B.: Spatial variability of recent sedimentation in Lake Ohrid (Albania/Macedonia), Biogeosciences, 7, 3333-3342, doi:10.5194/bg7-3333-2010, 2010c.

Wagner, B., Reicherter, K., Daut, G., Wessels, M., Matzinger, A., Schwalb, A., Spirkovski, Z., and Sanxhaku, M.: The potential of Lake Ohrid for long-term palaeoenvironmental reconstructions, Palaeogeogr. Palaeocl., 259, 341-356, doi:10.1016/j.palaeo.2007.10.015, 2008a.

Wagner, B., Sulpizio, R., Zanchetta, G., Wulf, S., Wessels, M., Daut, G., and Nowaczyk, N.: The last 40 ka tephrostratigraphic record of Lake Ohrid, Albania and Macedonia: a very distal archive for ash dispersal from Italian volcanoes, J. Volcanol. Geoth. Res., 177, 71-80, doi:10.1016/j.jvolgeores.2007.08.018, 2008b. 
Wagner, B., Lotter, A. F., Nowaczyk, N., Reed, J. M., Schwalb, A., Sulpizio, R., Valsecchi, V., Wessels, M., and Zanchetta, G.: A 40,000-year record of environmental change from ancient Lake Ohrid (Albania and Macedonia), J. Paleolimnol., 41, 407-430, doi:10.1007/s10933-008-9234-2, 2009.

Wagner, B., Vogel, H., Zanchetta, G., and Sulpizio, R.: Environmental change within the Balkan region during the past ca. $50 \mathrm{ka}$ recorded in the sediments from lakes Prespa and Ohrid, Biogeosciences, 7, 3187-3198, doi:10.5194/bg-7-3187-2010, 2010.

Wagner, B., Francke, A., Sulpizio, R., Zanchetta, G., Lindhorst, K., Krastel, S., Vogel, H., Rethemeyer, J., Daut, G., Grazhdani, A., Lushaj, B., and Trajanovski, S.: Possible earthquake trigger for 6th century mass wasting deposit at Lake Ohrid (Macedonia/Albania), Clim. Past, 8, 2069-2078, doi:10.5194/cp-8-20692012, 2012.

Wagner, B., Wilke, T., Krastel, S., Zanchetta, G., Sulpizio, R., Reicherter, K., Leng, M. J., Grazhdani, A., Trajanovski, T., Francke, A., Lindhorst, K., Levkov, Z., Cvetkoska, A., Reed, J., Zhang, X., Lacey, J., Wonik, T., Baumgarten, H., and Vogel, H.: The SCOPSCO drilling project recovers more than 1.2 million history from Lake Ohrid, Sci. Drill., 17, 19-29, doi:10.5194/sd-17-19-2014, 2014.

Wagner, B., Wilke, T., Wagner-Cremer, F., and Middelburg, J. (Eds.): Integrated perspectives on biological and geological dynamics in ancient Lake Ohrid, Biogeosciences, http://www. biogeosciences.net/special_issue209.html, 2015.

Watzin, M. C., Puka, V., and Naumoski, T. B.: Lake Ohrid and its watershed, state of the environment report, Lake Ohrid Conservation Project, Tirana, Republic of Albania and Ohrid, Republic of Macedonia, 2002.

Wijmstra, T. A.: Palynology of the first $30 \mathrm{~m}$ of a $120 \mathrm{~m}$ deep section in northern Greece, Acta Bot. Neerl., 18, 511-527, 1969.

Wijmstra, T. A. and Smit, A.: Palynology of the middle part (30-78 m) of a $120 \mathrm{~m}$ deep section in northern Greece (Macedonia), Acta Bot. Neerl., 25, 297-312, doi:10.1111/j.14388677.1976.tb00241.x, 1976.
Wilke, T., Albrecht, C., Anistratenko, V. V., Sahin, S. K., and Yildirim, Z.: Testing biogeographical hypotheses in space and time: faunal relationships of the putative ancient Lake Egirdir in Asia Minor, J. Biogeogr., 34, 1807-1821, doi:10.1111/j.13652699.2007.01727.x, 2007.

Wilke, T., Wagner, B., Albrecht, C., Ariztegui, D., Van Bocxlaer, B., Delicado, D., Francke, A., Harzhauser, M., Hauffe, T., Holtvoeth, J., Just, J., Leng, M. J., Levkov, Z., Penkman, K., Sadori, L., Skinner, A., Stelbrink, B., Vogel, H., Wesselingh, F., and Wonik, T.: Scientific drilling projects in ancient lakes: Integrating geological and biological histories, Global Planet. Change, 143, 118-151, doi:10.1016/j.gloplacha.2016.05.005, 2016.

Wolff, E. W., Chappellaz, J., Blunier, T., Rasmussen, S. O., and Svensson, A.: Millennial-scale variability during the last glacial: The ice core record, Quaternary Sci. Rev., 29, 2828-2838, doi:10.1016/j.quascirev.2009.10.013, 2010.

Wysocka, A., Grabowski, M., Sworobowicz, L., Mamos, T., Burzy'nski, A., and Sell, J.: Origin of the Lake Ohrid gammarid species flock: ancient local phylogenetic lineage diversification, J. Biogeogr., 41, 1758-1768, doi:10.1111/jbi.12335, 2014.

Zanchetta, G., Regattieri, E., Giaccio, B., Wagner, B., Sulpizio, R., Francke, A., Vogel, H., Sadori, L., Masi, A., Sinopoli, G., Lacey, J. H., Leng, M. J., and Leicher, N.: Aligning and synchronization of MIS5 proxy records from Lake Ohrid (FYROM) with independently dated Mediterranean archives: implications for DEEP core chronology, Biogeosciences, 13, 2757-2768, doi:10.5194/bg-13-2757-2016, 2016.

Zhang, X. S., Reed, J. M., Lacey, J. H., Francke, A., Leng, M. J., Levkov, Z., and Wagner, B.: Complexity of diatom response to Lateglacial and Holocene climate and environmental change in ancient, deep and oligotrophic Lake Ohrid (Macedonia and Albania), Biogeosciences, 13, 1351-1365, doi:10.5194/bg-13-13512016, 2016. 